\title{
MINE DEVELOPMENT - THE PRACTITIONER'S VIEW
}

\section{G. BARRY FINLAYSON and G. C. STEVENS*}

The framework for mineral exploration and development agreements is not always similar to the pattern developed for similar undertakings in the petroleum industry. This paper describes the basic formats for option agreements and - to the extent that there is any uniformity - joint venture associations that are commonly used in the mining industry. The role and the components of project financing in mine development are also briefly reviewed.

\section{INTRODUCTION}

This paper is intended to be a brief synopsis of certain aspects of the mining industry that are of particular relevance to the legal practitioner. The primary emphasis of this paper will be on the structuring of agreements which permit participation in the exploration for or development of a mining property. An overview of project financing, as it relates particularly to mine development, will also be presented. Except for a few peripheral observations in the course of this presentation, the many and complex income tax considerations that affect mining and exploration programs must be the subject of another paper. A brief discussion of legislation which regulates participants and the scope of participation in mineral exploration will be made, as well as a few concluding com.ments on environmental concerns. As we are British Columbia lawyers, references in this paper to legislation, unless specifically noted otherwise, will be to British Columbia statutes.

\section{INDUSTRY CONDITIONS}

\section{A. The Industry}

The finding and development of a mine is a long-term venture. The search for an economic ore deposit generally takes meny years and involves far more than the location of a sufficient tonnage of acceptable grade of mineral reserves. Extractive problems such as depth of overburden or water seepage, metallurgical problems such as deleterious substances that cannot easily be removed (and if removed, cannot be disposed of), transport, manpower sources, power supply, environmental impact and a host of other dilemmas will be met and resolved before an orebody becomes a mine. Thus, even when a promising property has been found, a considerable sum of money and countless hours of effort are required to prove the property to the point where a production decision can be made.

Once a production decision has been made, many millions of dollars are generally required to place the property into commercial production. As a consequence, project financing is generally required which will entail not only the mortgaging of all participants' interests in the property, but the sponsorship of a party with sufficient financial capability to ensure that all costs of over-runs will be met.

\section{B. The Vested Interest}

In many cases the party that finds an interesting exploration property is not one of the parties that eventually puts the property into commercial production. The initial finder of the mine will, however, generally retain some form of interest in the property

- Solicitors. Lawrence \& Shaw, Vancouver. B.C. 
and will eventually participate either in profits or in gross returns from the smelter or refinery. Often the finder of the property will be a small company or an individual who needs funds on a yearly basis to exist; who will not be able to participate pro rata in the costs of placing the deposit into production or even in development expenses; and who will, in every case, be keenly interested in having a continuous program of exploration conducted on the property until either the property is shown to be worthless or is shown to contain an economic orebody.

In some cases, the owner of the property will have some particular expertise in the area of mining exploration and development, and it will be advantageous to have that party participate in further development of the property. In other cases the owner may have certain plant and equipment which can be utilized in the exploration and development of the property. The development agreement must thus be structured to accommodate these matters.

\section{The Parties}

In mining situations, one does not generally encounter a plethora of parties holding small interests. Frequently the prospector or original vendor is the only party with a carried or royalty interest, for trading or similar dealing in mining properties with the broker retaining a small carried interest is not common in the industry. Rather, parties tend to hold their entire interest in properties and to work them as long as they can. Applicable legislation permits them to hold properties by doing a nominal amount of work each year and, accordingly, the property owner can wait for the partner that will ultimately find the mine.

As a result, a "work it or leave it" philosophy is a fundamental tenet of the owner's approsch to mineral exploration agreements, and prevents an optionee from acquiring a vested interest in the property - despite possibly large expenditures - unless the optionee commits to place the property into production. It is not uncommon for a mine to be brought into production thanks in no small part to the results of work done by faint-hearted optionees who gave up too soon, and who not only take no share of the proñts, but do not even recoup their investment in the property.

\section{The Legislation}

Legislation in each jurisdiction dictates what minerals one may look for. In British Columbia, the Yukon and the Northwest Territories, for example, there are separate statutes or regulations to deal with minerals in situ, minerals lying a distance from their origin, and coel. The solicitor must, therefore, be aware at the outset of the minerals for which his client is looking. The applicable statutes in British Columbia are the Mineral Act for minerals in situ, the Mining (Placer) Act ${ }^{2}$ for minerals lying a distance from their place of origin, and the Coal Act ${ }^{3}$. Crown granted mineral claims still exist in British Columbia, although they are no longer granted. These represent original grants in fee from the Crown and are subject to the Land Title Act rather than the Mineral Act. To keep them in good standing one must pay yearly land taxes.

The mineral acts and regulations specify the persons who may participate in the exploration and development of mineral properties. They prescribe the manner in which participation may be effected by the acquisition of mineral rights through the location of mineral claims, and they specify the rights which the claim holder has to explore for and mine minerals.

1. R.S.B.C. 1979 , c. 259.

2. R.S.B.C. 1979, c. 264.

3. R.S.B.C. 1979, c. 51.

4. R.S.B.C. 1979, c. 219. 


\section{WHO CAN PARTICIPATE}

\section{A. Provincial Legislation}

Provincial legislation imposes certain requirements which a participant must meet before he may obtain rights to minerals in place in the Province. Under the British Columbie Mineral Act a participant must be a "free miner" and must obtain a Free Miner's Certificate in order to participate in the exploration for and development of mineral deposits within British Columbia. The Act provides, in subsection 2(1), that "no person shall prospect or explore for, locate, mine, or produce minerals or acquire title to a mineral claim or leasebold unless he is a free miner; but a person employed by the holder of a mineral claim or leasehold to prospect or explore for, mine or produce minerals need not be a free miner".

That Act provides that the Gold Commissioner is to issue a Free Miner's Certificate to an applicant who is:s

(a) 18 years of age or over and is a Canadian resident, or

(b) a Canadian corporation.

In turn, "Canadian corporation" under that Act means"

(a) a company incorporated under the British Columbia Companies Act or one registered in the Province extra-provincially, or

(b) a trust company registered under the Trust Companies Act, or

(c) an insurance company licensed under the Insurance Act, or

(d) a chartered bank

in which at least $50 \%$ of the directors are Canadian residents. "Canadian resident" under that Act means a person, other than a corporation, who is ordinarily resident in Canada and who?

(a) is a Canadian citizon, or

(b) if not a Cansdian citizen, has not, at the date he applies for, or applies to renew, a Free Miner's Certificate, been ordinarily resident in Cansda for a continuous period of more than eight years.

It is interesting to note that the participant need not be a company controlled by $\mathrm{Ca}$ nadian residents through the ownership of shares, but must merely have a board consisting of not less than $50 \%$ Canadian residents.

It should also be kept in mind that the holder of a Crown granted mineral claim in British Columbia need not hold a Free Miner's Certificate since Crown granted claims are real interests governed by provisions of the Land Title Act."

\section{B. Federal Legislation}

Federally, there are statutes and regulations governing mining exploration and development in the Yukon and the Northwest Territories. Additional statutes as well as policies that are not yet wholly defined govern the acquisition of uranium rights throughout Canada. Over all mineral exploration adventures hangs the impenetrable cloud of the Foreign Investment Review Act" which places restriction on participation by non-eligible persons in the mineral industry in Canada. The requirements of the Foreign Investment Review Act are outside the scope of this paper. However, it should be kept in mind that exploring for minerals may not be a "business" within the meaning of the Act, but the non-eligible person that finds a mine (that is not a "related business") without first having secured Agency approval subjects itself to considerable financial risk as well as potential delays in developing the orebody.

\footnotetext{
5. Supra n. 1. s. 2(3).

6. Id. at s. 2(2).

7. Id.

8. Supre n. 4 .

9. S.C. 1973-74, c. 46.
} 


\section{FORMS OF PARTICIPATION}

There are three basic methods of participation in the mineral exploration industry:

(i) a person can acquire mineral interests by staking mineral claims or otherwise acquiring mineral interests directly from a Government under applicable legislation, either alone or in concert with one or more other persons under some joint arrangement;

(ii) a party can acquire mineral interests by a direct purchase of mineral rights from another party; or

(iii) a party can acquire an interest in a mining property by performing work on another party's property, the work itself being the consideration that entitles the party to earn an interest in the property.

\section{A. Acquisition by Staking}

To participate by staking mineral claims a person must meet the requirements of the applicable mineral legislation, including those related to the locating and recording of mineral claims. The continued right to hold the mineral claim will depend upon the person meeting certain requirements set out in the legislation, which generally relate to the payment of a minimum sum per year as a registration fee together with a requirement that a minimum amount of exploration or development work be performed on the mineral claims, or that a specified payment be made in lieu thereof. The type of work which is acceptable for filing is governed by applicable regulations. Not all work performed on a property may qualify as assessment work, a factor which must be taken into account in option agreements that require the optionee to perform specified minimum amounts of work.

\section{B. Purchase of Existing Mineral Rights}

In purchasing existing mineral rights the purchaser will attempt to obtain from the vendor the usual warranties of title, as well as warranties that the mineral claim or claims in question have been staked and recorded in accordance with required laws, and have been kept in good standing by the filing of work and the payment of fees. If the mineral claims have not been surveyed (and that is usually the case) the vendor's warranties should rellect this frailty.

The transfer is effected by the completion of a bill of sale and its registration in the appropriate mineral registration office. The registration of the bill of sale will not, how. ever, perfect title as under a land registration system. For example, nothing in the statute provides that an option agreement executed after, but recorded before, a transfer of a mineral claim takes priority over the late registered transfer.

In British Columbia the bill of sale will not be accepted by the mining recorder unless all parties thereto have valid Free Miner's Certificates.

\section{Acquisition through an Option Agreement}

\section{Introduction}

As indicated above, the main purpose of this paper is to describe agreements relating to the acquisition of mineral interests. The most common type of agreement is an option agreement whereby a party earns an interest in another person's mining property by conducting a certain amount of exploration work on that property. These agreements generally follow one of the following formats:

(i) the acquiring party (the "optionee") earns, for example, a 70\% interest in the property and, thereafter the optionee and the owner at the time of execution of the agreement (the "optionor") pay (usually pro rata to their interests) for further expenditures on the property under a joint venture agreement, or

(ii) the acquiring party earms a $100 \%$ recorded interest in the property subject to a net profits or net smelter returns interest retained by the vendor.

There is attached as Appendir "A" a typical option agreement which provides for the earning by a party of a $100 \%$ recorded interest in the property, subject to a $20 \%$ net profits interest retained by the vendor. 


\section{The Agreement}

The following is a discussion of the terms of the Option Agreement.

\section{(a) Recitals}

Recital (B) sets out the terms of the grant. The optionee will earn an interest in the property by not only performing work on the property but also by committing to place the property into commercial production. This is a normal situation and one which the optionor should always attempt to negotiate. The optionor will not wish to have his interest in a property diluted, or his right to deal off the property affected, except by a person who commits to place the property into production.

In agreements which provide for both parties to end up with a working interest, it is not uncommon to allow a party to eam an interest without committing to place the property into commercial production.

\section{(b) Consideration}

The amount of money paid as initial consideration varies tremendously from transaction to transaction. The amount of money which can be obtained from the optionee will depend not only on the financial resources of the optionee but on the state of the property, and in particular on the amount of exploration previously conducted on the property and the mineral showings defined as a result. The particular interests of the optionee, such as ownership of adjacent properties or a nearby mill, must also be taken into account.

The small mining company will almost certainly require some cash consideration as the means of its survival, and to help defray the costs of its continued stock exchange listing. However, some small companies are often willing to forego large "up-front" pay. ments with a view to having the property explored, with consequent enhancement of value.

\section{(c) Representations and Warranties of the Optionor}

Section 2 of the agreement sets out many of the usual representations and warranties of the optionor.

Subparagraph 2(a)(ii) relates to compliance with applicable mineral legislation, and includes a warranty that the mineral claims were validly located and recorded under the applicable Mineral Act and that they are in good standing in the office of the applicable Mining Recorder. That statement is important since the proper staking of a mineral claim can go to the root of title. That is, if it can be shown that the mineral claims were not staked according to applicable laws, a challenge to the validity of the claims may result in the mineral claims being invalidated. Similarly, a properly located mineral claim is void under the British Columbia Minerel Act if it is not recorded within the prescribed time. ${ }^{10}$

Subparagraph 2(a)(iii) contains a warranty that no adverse claims or challenges against ownership of title exist. That statement would relate to other parties claiming an interest in the mineral claims through the staking of mineral claims in the same area, or it could relate to other interests alleged to have been earned contractually. The latter point is covered by the next part of that paragraph.

Subparagraph 2(a)(vi) will be important if the optionor is a small company which may have only one or two properties. Section 149 of the British Columbia Companies Act" provides that the directors may not sell all or substantially all of the assets of a company without receiving shareholder approval by way of special resolution (a majority of two-thirds of the votes cast). The disposition of a mineral claim or a group of mineral claims, which is the sole asset of a company, even where the company reserves a royalty interest, could be construed as a sale of substantially all of the assets of a company. 
While it may be said that only the exercise of the option, and not the grant, is subject to approval of the optionor's shareholders, that fine distinction is cold comfort for the optionee. If approval is required, it should be obtained before any signficant consideration is paid.

\section{(d) Representations and Warrainties of the Optionee}

Section 3 sets out the representations and warranties of the optionee. The agreement presented contains only the usual representation as to corporate status both as to incorporation and the ability to hold mineral claims. The latter warranty verifies compliance with the terms of applicable legislation respecting capacity to hold mineral claims in the Province or Territory in question. In British Columbia, this would oblige the optionee to hold a valid Free Miner's Certificate, and, in the case of a company, to be registered in British Columbia and to meet the director requirements discussed earlier.

In this Section one must also consider the applicability of the Foreign Investment Review Act. ${ }^{12}$ It would be appropriate to include a statement that the optionee is not a non-eligible person under the Foreign Investment Review Act, if such is the case.

\section{(e) Acquisition of Option}

Section 4 sets out the mechanism for acquiring an interest in the property. The agreement in question provides for the payment of yearly fees in order to maintain the option in good standing. The amount of money involved is always negotiable, with the optionor wanting as much money as possible and the optionee arguing that the money is better invested in the ground than in the optionor's bank account. As discussed earlier in the paper, many of the holders of interests in mining properties will be small public com. panies that will need a minimum of $\$ 10,000$ to $\$ 20,000$ a year to maintain their corporate existence, and accordingly, that is the minimum amount of money that the optionee may reasonably be expected to pay to an optionor. Obviously, the more promising the property, the higher the yearly payments will be.

\section{(f) Exercise of Option}

Section 5 sets out the mechanism for exercising the option, as compared to the mechanism in Section 4 for keeping the option in good standing. In the attached agreement, a base amount of $\$ 1,000,000$ has been fired as the amount of money required to be spent on the property before the option may be exercised. This figure should be based upon the optionor's best estimate of the minimum amount of money which must be spent on the property before any decision may be made respecting a production commitment.

One often finds in this clause the requirement that if the production commitment is given, the property must be placed into production within a set period of time; otherwise, the optionee earns no interest. That type of clause puts added emphasis on the optionee's obligation to place the property into commercial production.

In the agreement attached, subparagraph $5(c)$ merely requires the optionee to proceed without delay to place the property into production. If it is decided that a definite time limit for production should be placed in the agreement, one must take into consideration the nature of mining operations to take place on the property, whether a mill must be constructed, and whether other phases of development must be undertaken on the property. The more development work that is necessary, the more time, of course, that should be given for the placing of the property into production.

\section{(8) Right of Entry}

The right of entry clause contains customary terms with respect to the obtaining of quiet possesion of the property and the right to enter and use the property. Here, it is important that the optionee be given the right to erect buildings, plant and machinery on the property since core sheds and other facilities, including accommodation, will be required during the course of exploration activities on the property. In many cases, a small

12. Supro n. 9 
pilot plant will be constructed on the property as part of a feasibility study prior to any production commitment.

It is important, as well, that the optionee have the right prior to the production commitment to mine and dispose of ores, minerals and metals for the purpose of obtaining assays and making other tests. In this agreement, the net revenues derived from those reasonable samples do not accrue to the optionor directly, but rather will accrue to the net profit account and will eventually act as a deduction from preproduction expenses. With the present prices of gold and silver the optionor may suggest that the net revenue derived from precious metals taken from the property should be split by the parties. The amount of money could be substantial and could be a means of providing the optionor with early cash flow.

\section{(h) Transfer of Property}

Certain matters must be attended to each year in order to keep mineral claims in good standing. Assessment work in respect of mineral claims under the British Columbia Mineral Act ${ }^{13}$ must be filed each year; in the case of Crown granted mineral claims, there will be tares to pay every year. Various other assessments may also be made in respect of mineral properties under other provincial statutes, all of which are more conveniently dealt with if the mineral claims are registered in the name of the party that is conducting work on the property.

In addition, since the Mineral Act contains no assurance of title to an optionee, it is decidedly more secure for the optionee to have the property registered in its name. Accordingly, paragraph 7 of the agreement provides that upon execution of the agreement the optionee will obtain a transfer of the mineral claims into its name. Another advantage of this procedure is that when the production commitment is made, no further steps need be talsen in order to effect the transfer to the optionee of title to the mineral claims. Nor would the optionor need to take any further steps to register his royalty interest since, upon execution of the agreement, the mineral claims would be registered in the name of the optionee at the applicable Mining Recorder's office and the agreement, or an extract of the agreement setting out the bare terms of the option and of the royalty, would be registered against the mineral claims.

This is a very important clause and one that an optionee should always attempt to obtain. But by the same token, if the optionor has misgivings over the financial capability or the integrity of the optionee, he will attempt to forestall transfer of recorded title until a production decision is made.

An alternate procedure which is sometimes used, but which is cumbersome, is to have the transfers of mineral claims executed, undated, and held in escrow for release to the optionee upon certain events occurring. The problem here is not only that the optionor remains as the recorded owner and the optionee, when it files work reports, must state that it is performing work on behalf of the optionor, but also the optionee must then ensure that the optionor maintains a Free Miner's Certificate throughout the term of the option.

Nor will transfers in escrow prevent fraudulent dealings by the optionor. The only way to prevent this danger is to bring in a separate escrow holder of the claims, and ensure that such fiduciary is and remains legally entitled to hold the mineral property.

(i) Obligations of the Optionee During Option Period

Section 8 of the agreement sets out the optionee's obligations during the option period. The right under subparagraph (b) to allow directors, officers, employees and consultants of the optionor to enter on the property is important since many optionors will have a keen interest in the development of the property and will wish to monitor the optionee's progress.

Subparagraph (c) sets out another provision designed to ensure a monitoring of progress on the property. This clause requires the optionee to deliver semi-annual reports. It

13. Supre n. 1. 
is important to consider how many reports are reasonable and what those reports should entail. The description given in the agreement is fairly brief. One can of course go into much more detail and specify eractly what the reports are to contain. The reports will be important for an optionor, not only for management purposes, but also to enable it to report to the company's.shareholders on the progress of the work on the property. Some larger companies are hesitant in giving out timely information relating to their activities on a property due to a fear that the smaller optionor will use the information for stock promotions. Section 16 is intended to restrict this gambit. However, if the optionor is a public company it will noed reports.

A further provision that is frequently included in this Section is an obligation on the part of the optionee to record the maximum amount of work possible against the mineral claims. In British Columbia, work can be applied against mineral claims for a period of ten yeara. To do that, a filing fee for each year must be paid. That fee is only $\$ 5.00$ a year and is not of a nature to discourage a company from recording excess work. However, many optionees do not wish to record all the work done because it means preparing more extensive reports on the property and organizing work in a fashion which complies with the regulations under the Mineral Act. An optionor should nonetheless insist that all work performed on a property be recorded. If the mineral claims are returned to him, he will want them to be in good standing for as long a period as possible.

\section{(j) Termination of Option}

The above observation is reflected in Section 9, which deals with the obligations of the optionee upon termination of the option, otherwise than by exercise.

Subparagraph $9(a)(i)$ provides that mineral claims are to be left in good standing for a period of at least 90 days. That is not very long. Under the British Columbia Mineral Act claims are rept in good standing on a year-to-year basis.14 Accordingly, an optionee should attempt to have the mineral claims left in good standing for a minimum of one year. If the property is in a mountainous area, the work season may be short, in which case care must be taken that the claims are left in good standing to a date that extends beyond the next work seeson. Under subparagraph 9 (a)(ii) the optionee is to deliver a bill of sale in recordable form to the optionor upon termination. Here the optionor should try to impose upon the optionee the obligations to have that bill of sale recorded and to pay for the recording.

Subparagraph 9(a)(iii) provides for the delivery of technical information to the optionor. The prime resson for the optionor entering into the arteement was to have exploration work performed on the property and accordingly the optionor should obtain the benefit of that work.

Subparagraph $9($ b) is important to the optionee since it allows him time to remove his plant and equipment from the property after the date of termination of the option. The time period given will depend on the location of the mineral claims. Generally, mineral claims in Canada are in remote locations, so that four to six months will be required to remove the plant and equipment. The clause also provides that if the plant and equipment are not removed in that time period, title thereto vests in the optionor. Where no such revesting provioion was placed in an agreement, there have been disputes as to ofnership of and responsibility for the plant and equipment.

The optionee should also attempt to include in the agreement an obligation on the part of the optionor to remove any equipment and remedy any work such that nothing will be left on the property that could constitute a nuisance.

\section{(k) Royalty}

Section 10 of the agreement is the royalty provision. The obligation revolves around the definitions of "net profits", "gross revenues", "operating expenses" and "preproduction expenses".

14. Id. at a. 22(1). 
The magnitude of a royalty interest varies from property to property. However, it is fairly standard in the industry today to have that interest set in the order of 20\%. It appears extremely difficult to negotiate a higher royalty interest unless the property, at the time of the grant of option, has been "proved up" to a fairly substantial degree.

The royalty provision in the agreement relates to payback. That is, the optionor receives no royalty until the optionee has recovered all of its expenses incurred in respect of the property. Accordingly, the net profits account must exceed the total of the preproduction expenditures and the operating expenses before a royalty is payable:

\section{(i) Preproduction Expenditures}

The definition of preproduction expenditures is very broad and is intended to include essentially everything that the optionee has expended in respect to the property. It is not unusual, however, to exclude the option payments from this account. The rationale for this exclusion is that the optionee should only recover expenses which it has actually put into the ground, and accordingly the payments made directly to the optionor are excluded. One does not generally differentiate in the definition of preproduction expenditures between capital and non-capital items. Thus, the period during which the preproduction expenditures account accumulates is from the initiation of the option to the date of commencement of commercial production from the property. After the date of commencement of commercial production, all expenses relating to the property will be operating expenses, which again is a defined term.

Associated with the actual exploration and development expenses will be office overhead expenses which are legitimate charges against exploration and development of a property. Since it is not possible to ascertain the exact amount of those expenses, there is generally a blanket percentage placed in the agreement, such being a percentage of the total amount of funds directly expended on the property. The attached agreement reflects the fact that the overhead burden should not be applied equally on all expenditures.

In recent times, with markedly higher financing costs, optionees insist that the preproduction account be credited with an interest factor. That is incorporated in clause (iii).

\section{(ii) Net Profits}

Net profits are the basic factor in determining whether payment of a royalty under this agreement is required. Net profits are defined for any year as the gross revenue received in that year less, successively, all operating expenses incurred by the optionee during the year, and any excess of operating expenses over gross revenues for all prior years to the extent that such excess has not been previously deducted in computing net profits.

First of all, there must be net profits in order for the preproduction account to be paid down. A preproduction expenditure account is established together with a net profits account. Net profits will not result until all revenues exceed all operating expenses, on a cumulative basis from the time of commencement of commercial production. When the operation becomes profitable and there are net profits in a year, those net profits go towards decreasing the preproduction expenditure account. It is not until that account has been depleted that the royalty of $20 \%$ of net profits attaches. That may take a number of years, at which time further capital expenditures will be required to keep the property in an economic state of development. Those expenses will be treated as additional operating expenses under the definition, and will delay the date when net profits (for the purpose of royalty) are finally realized.

Because the capital cost of all fixed assets will be included in operating expenses, depreciation and amortization are excluded. 


\section{(iii) Advance Royalties}

If the optionor becomes despondent at the prospect of seeing no royalty for years after commencement of production, one method of providing him with early cash flow is to make provision for payment of a yearly sum commencing on the expiration of the first full year of commercial production, whether or not a royalty based on net profits is payable. If such a royalty is not then payable, the payment will be treated as an advance royalty and will be deducted from future royalties payable.

\section{(1) Power to Charge Property}

Section 11 of the agreement permits the optionee, after the exercise of the option, to mortgage the whole interest in the property for the purpose of raising funds to place the property into commercial production. This is extremely important since a bank or other financial institution will not lend funds to finance a mining operation unless the loan is secured by the whole interest in the property. The reference to the requirement that the mortgagee acknowledge the interest of the optionor is not placed in the agreement for the purpose of establishing the optionor's overriding interest, such to be outside the terms of the mortgage; but rather will mean that if the mortgage is enforced and the property is sold or operated by the mortgagee, at such time as there are net profits, the optionor will obtain his net profits interest.

\section{(m) Transfers}

Subparagraph 12(b) reflects the reluctance in the mining industry to permit a multiplicity of parties. That clause provides that if the optionee transfers other than its entire interest in the agreement and in the property, then it will remain as a covenantor. That will not, however, be the case if its entire interest is transferred.

\section{(n) Surrender of Property}

Section 13 gives the optionee the right to surrender parts of the property taken under option. This reflects the fact that during an exploration program, certain parts of the property may in fact appear to be useless from an exploration point of view and it may be felt that the continuing expenditure of funds to keep those mineral claims in good standing is not warranted. Accordingly, the optionee may without terminating the agreement release those unwanted claims either by transferring them back to the optionor, if the optionor so requests, or by allowing them to lapse.

It should be noted, of course, that barren mineral claims have a value if they are adjacent to a mineral deposit. If a property is to be placed into commercial production, waste areas are always required, as are sites for the concentrator, the mill, other plant and equipment and for tailings ponds and stockpiling areas. As a result it is generally felt that if a major exploration program is being carried out on a group of mineral claims, all of the mineral claims should be retained, and surrender of part interests is not common.

\section{(o) Discontinuance of Operations}

Paragraph 14(c) permits the optionee to suspend or curtail mining operations when in its opinion it has sufficient stockpiles of ore, or markets are not available to absorb production. Care must be taken to ensure that the optionee does not commit to continuous production until exhaustion of ore reserves.

Paragraph 17(b) sets out the optionee's right to discontinue mining operations on the property if, in its opinion, no further mining operations can economically be carried out. This clause then places on the optionee the obligation to sell the property; the proceeds of the sale would be classed as gross revenues and included in the net profits account. If the optionee intends to use the mining assets elsewhere, it should account for them.

\section{Joint Venture Agreements}

The petroloum lawyer, when first exposed to the mining practice, is invariably surprised at, and critical of, the absence of any standard form of joint venture agreement 
for the governance of joint mining or mineral exploration activities. The standard forms of leases and operating agreements adopted by the oil landmen have no counterparts in the mining industry.

There are ressons, of course, for this absence of uniformity, some of them even meritorious. The comparatively recent transition - thanks to changing tax laws - from association with other participants through the " 750,000 share" company to joint venture union, coupled with problems (which indeed are shared if not fomented by lawyers) in comprehending the true nature of a joint venture and the rights and duties of the participants therein, have inevitably led to the development of different approaches to, and different styles of, joint venture relationships.

But another more compelling explanation for the lack of uniformity lies in the conviction of many mining companies that they have talents in devising programs of exploration and development that are not shared by others, and which must be given the chance to be displayed, or at least protected, in the joint venture relationship. Many years' work will be done after the exploration joint venture is formed before an economic orebody is delineated. Throughout that period, different philosophies may dictate the nature and extent of the exploration program. After the mine is proved, the objectives, the financial capabilities and - in the case of the "major" mining companies - the priorities in mine openings, of each participant will impact upon the scope and timing of a production decision. There is no standard orebody, there is no uniform exploration program, and there is no conventional mining company.

What one has then, in the formation of a mining joint venture, is a very personal relationship among participants that must reflect the particular strengths and concerns of the members; and yet the agreement that will govern that relationship must be - like our constitution was intended to be - a living tree that can be adapted to ever changing circumstances, such as all the vagaries of underground exploration, international commodity markets and uncomprehending - if not unsympathetic - governments. Until a model code for joint relationship is developed that can accommodate the diverse objectives and limitations of all types of participants, there will be no uniformity.

While joint venture agreements may thus differ substantially depending upon the participants, in most there are common threads that bind the relationship, or common gituations, that must be dealt with, either positively (the "Operator" has discretion to act) or negatively (nothing can be done without unanimous consent). The form of joint venture agreement attached as Appendix "B" is an example. In that particular agreement the joint venturers propose to explore property acquired from a third party under option, rather than to locate their own prospect.

\section{(a) Objectives}

A joint venture agreement should contain a statement of the objectives of the joint venture. That statement is included in Section 2 of the attached agreement. This section also provides for the amount of an initial approved exploration program. Usually the parties will have agreed on the first year's program prior to formation of the agreement. In some cases the initial program will be the blueprint for several years' activities, except as the program may be altered by the participants as work results are analysed.

\section{(b) Management}

The provisions contained in Section 3 define the scope of the management responsibilities of the joint venturers.

The over-riding governing body of a joint venture is a management committee. This committee does not get into the day-to-day operations of the joint venture, which are the responsibility of the Operator. However, the committee establishes policies and approves budgets. There must inevitably be debate whether the management committee is like a board of directors with only general supervisory and policy-making powers, or whether it is in fact a body representative of the partners, with all the powers and responsibilities of general partners. The concept of partnership control and participation (and what is a 
joint venture in essence but a limited purpose partnership?) will be most severely tested where one party has a greater than $50 \%$ interest.

The agreement establishes the manner in which the management committee is to be organized, and sets out the basic rules for its administration. Here reference must be made to the number of representatives that each joint venture participant will have on the management committee and the voting power members of the committee will have. The Section will set out the mechanism for calling meetings, the quorum for meetings and how matters will be voted upon at the meetings. Paragraph $3(b)$ sets out certain matters which are within the sole jurisdiction of the management committee. These include:

(i) the approval of budgets;

(ii) the approval or purchase of equipment;

(iii) the approval of contracts over a specified sum;

(iv) the approval of dispositions of equipment having certain values;

(v) the approval and replacement of the operator;

(vi) the approval of abandonment of property;

(vii) all decisions relating to the status of the property in question.

(c) The Operator

Sections 4 and 5 of the joint venture agreement deal with the term of appointment and the responsibilities of the Operator, and the fees which the Operator is to be paid. The Operator is usually the party with the greatest participating interest in the joint venture, or (particularly where two venturers have equal interests) the participant that either knows the property best or supposedly has greater expertise.

The matters which must be dealt with respecting the Operator's tenure are:

(i) the appointment of an Operator initially;

(ii) how an Operator may resign;

(iii) how an Operator may be removed;

(iv) how a new Operator may be appointed; and

(v) what fees the Operator will be paid.

Because a mineral exploration program will be conducted over a period of several years, and because of a conviction that continuity of management is desirable throughout that period, it is unusual to include provisions that entitle the non-operator to propose and to implement programs, and in that way to replace the Operator.

Section 5 sets out the responsibilities of the Operator, which will involve, as a minimum, the performance of sufficient assessment work in each year to keep the property in good standing. The Operator will be given the responsibility for proposing all exploration programs on the property, such proposals to be presented to the management committee for approval (with or without amendments). In addition, all day-to-day matters relating to the exploration and development activities on the property must be carried out and attended to by the Operator subject to certain contractual matters which may be subject to referral to the management committee. The Section is very comprehensive and the extent to which the Operator's authority is restricted in any instance will depend upon the negotiating power of the non-operator.

\section{(d) Non-Participation}

A key part of any joint venture agreement is the provision for the consequences of a party's failure to participate in a work program. All agreements should have a mechanism to permit a party, after it has expended some amount, to decline to participate in a program it disapproves of without forfeiting its entire interest. At the same time the agreement should reflect the fact that exploration activities must be allowed to go on, so that if a party neglects or refuses to participate in a work program, its interest in the property should be accordingly diluted.

In Section 6 of the draft agreement, the Operator is given the power to implement a minimum work program each year in order that the property will be kept in good standing. Such a program would be implemented even if the management committee 
could not agree on a program. In paragraph (d) the parties must continue to participate until joint venture expenditures total $\$ 1,000,000$. If a party fails to do so, it will earn no interest in the joint venture property and will forfeit any interest which it had to the other participant. After $\$ 1,000,000$ has been expended by the joint venture, a participant may elect not to participate in an exploration program or to participate at a reduced rate to an extent of not less than $3 \%$ of its maximum permissible level.

The dilution provisions require very careful consideration, particularly in agreements where a large company will earn, for example, a 70\% working interest in a property, and the other $30 \%$ is held by a reasonably small company or an individual. If it turns out that a large amount of money must be spent on the property for exploration prior to any production commitment being made, or if the joint venture is organized in such a way that either party may commit to place the property into commercial production, the small party may not be readily able to come up with funds required for its share of the joint venture costs. In that case, the agreement should contain a liberal time period during which the small company can raise the funds. Such a period will be much longer than the usual 20 or 30 days during which time a party must respond to a call for operating funds, and may indeed be as much as a year.

There is no magic moment when the results of exploration, development and feasibility work inarguably prove that the project is a mine. Each party to the agreement will have its own views on capital costs, mineable reserves and, most importantly, future metal prices. Markedly divergent opinions will result in one party pressing for an early production start, and the other urging delay. The problem is not readily resolvable in a venture where the participants have equal interests, and can be considered either stifling (where the minority participant wishes to proceed) or overbearing (where it does not) in the case of a joint venture composed of majority and minority interests.

The attached agreement provides one formula for resolving this problem: a buy-sell or "shotgun" formula to resolve deadlocks. If a party cannot, in two years, persuade the others to proceed with production, he will value the participating interests and irrevocably offer to sell his interest at the price that corresponds to his proportionate share of the total participating interests; and, if the offer is not accepted, it will purchase the offerees' interests on the same proportionate price basis.

Such a formula is effective but not wholly satisfactory, particularly for a party with limited resources which must share the risk with other partners if the property is to be put into production, and which may find it difficult therefore to find the purchase price required to trigger the shotgun. Further, at this critical juncture in development of the mine, the owner's resources should be devoted to mine construction, and not reimbursement of another person.

Another solution to the problem - one that is easier in the concept than in the definition - is to prohibit the implementation of a production decision (in the absence of unanimity) unless the proposer has produced a "bankable" feasibility study: one which is of sufficient quality and so demonstrates the viability of the project that major lending institutions would, on the basis of that document, provide the required capital funds on a project loan basis. This attempt to replace the subjective opinions of each participant by, it is hoped, empirical and objective conclusions will serve two purposes. In the first place, it will reduce, if not eliminate, the likelihood of one participant forcing another to commit substantial sums to an uneconomic or marginal project. Secondly, almost every mining company in Canada will employ debt financing as the major source of construction funds. A commitment that must be based on a feasibility study acceptable to lenders will give considerable assurance that, so long as the other security requirements of the lenders are available, the participant will obtain the financing that it requires.

Unfortunately, because joint venture agreements are made long before the size or even the existence of an ore body is known, it is difficult to define in advance the parameters of a "bankable" feasibility study. Careful negotiation, skillful drafting and ample good faith are required to produce an acceptable definition. 


\section{(e) Taking Production in Kind}

Section 10 provides that each participant will take its share of production in kind. This may not be an appealing feature to the parties, particularly if one has marketing expertise which it wishes to extend to all production from all joint venture. However, in the eyes of Revenue Canada the right (or perhaps obligation) to take production in kind is one of the "badges" of a joint venture relationship. Without it, the association may be viewed by that authority, and taxed, as a partnership. Should that occur the participants would forfeit one of their principal objectives, namely the ability to account separately for profits, losses, and charges such as depreciation affecting their respective income statements.

\section{(f) General Comments}

The remainder of the joint venture agreement relates to a number of subjects which must be dealt with in such agreements. Section 11 provides that the liability of participants is separate and not joint. As against third parties, the clause is more a pious wish than an accurate statement of the law, but its inclusion does no harm and it does reflect the rights of the parties inter se. Separate as the interests of the parties may be, the agreement should provide that there may be no partition of the property during the term of the agreement.

In many ways, then, the terms of the joint venture agreement are far more negotiable and less usual than those contained in an option agreement. Also, the terms are determined much more by the relationship between the parties to the agreement than is the case in other types of exploration agreements. In drafting the joint venture agreement, one must anticipate what types of expenditures will be made, what the parties' expectations are in having yearly exploration work done on the property, and what expectations parties have with respect to the other parties' initiative in funding the venture. These and many other factors will determine how the joint venture agreement is structured.

\section{PROJECT FINANCING}

As development of an orebody passes from the exploration stage to the feasibility stage, the owners of the property must focus their attention on the means of raising the very substantial amounts of capital which will be required to place the property into production. For all but the handful of resource companies which have available undrawn lines of credit messured in hundreds of millions of dollars, there will be no inconsiderable impetus towards the securing of capital on a project finance basis.

It would be unusual for two mining projects to secure production financing in precisely the same manner or upon the same terms. The location of the mineral deposits, the nature of the minerals to be extracted, the availability of transport, the existence or necessity for social and support intrastructure, the market for the minerals, the number, and the financial capability, of the participants - to name but a few variables - will all lead to the development of a financing model that will be unique to the particular project. Nevertheless, the availability of project financing in any instance is dependant upon the existence of certain key elements, and it is those building blocks to the formation of capital under a project finance loan that are discussed below.

\section{A. Project Financing: What is it?}

Project financing has been defined as the financing of a particular economic unit in which a lender is satisfied to look initially to the cash flow and earnings of that economic unit as the source of funds from which a loan will be repaid, and to the assets of the economic unit as collateral for the loan. In short, the perfect theoretical model for a project finance loan will be a free-standing undertaking with assets and projected earnings of such credibility that the lender will advance the funds required to place the project into production without assurances of repayment from sources other than the project.

Unfortunately for the mine developer, that model of the project finance loan remains just that - a theoretical model to which the lenders will pay lip service before imposing 
their demands for collateral guarantees of payment and debt service. The lender will look initially to the cash flow and earnings for retirement of the project finance loan, but only if a financier acceptable to the lenders has guaranteed that the project will begin to generate cash flows at predicted rates by a stipulated date, and only if sales contracts or other agreements are in place that ensure adequate revenues through the life of the loan sufficient to service the indebtedness.

\section{B. Why Project Finance?}

The mine developer is not likely to proceed with a project unless a feasibility study discloses that the project, as a self-contained integral unit, will not only repay in comparatively short order all costs to be incurred to place the project into production, but will thereafter produce a satisfactory rate of return to the developer. Once the economic viability of the project has been so established, the developer cannot help but assume that the lenders will share his enthusiasm, and will be prepared to make advances to the project on the basis of the viability of the project presented by the feasibility study, and not on the general credit of the developer, or on the security of assets used in other undertakings.

A true project finance loan will not be a general charge on the assets of the developer, but only on those assets required for the project. The other assets will remain unencumbered and available for use by the developer in whatever manner he requires for the conduct of his business apart from the new mine.

This "sanitized" approsch to project financing is used for divergent purposes - and with divergent results - by the developer and by the lender. The large, heavily capitalized mining company may apply the project finance test to a new mine not necessarily as the means of raising capital, but rather as an empirical test for the viability of the project. Once having 80 satisfied itself, the company may well proceed to borrow the required funds from its bankers merely on its general credit and with no further consideration of the mechanics and strictures of a project finance loan.

On the other hand, the company of limited resources will produce the feasibility study, the construction contract, the sales agreements - in short, many of the pieces required to complete the project finance puzzle; but without its own general credit of a standard acceptable to the lender, the venture will not proceed unless guarantees of project completion are furnished from external sources. There is often an irony, then, in the fact that the more appropriate a new development is for project financing, the less is the developer's requirement for that form of assistance.

But even major companies will at times participate in project financing. The enormous capital requirements to place a new mine into production, coupled with the very considerable risks through (and perhaps extending beyond) the preproduction stage, often result in mining projects in which ownership is shared by a number of entities. Further, it is not uncommon for the "junior" mining company which found or otherwise acquired the property at a grass roots stage to maintain a minority working interest (that is, an interest that is not merely a royalty or retained profits interest not requiring any further outlay of moneys) in the project. It follows that the financial integrity of the respective owners may vary substantially. And from that it follows just as surely that the affluent parties will not accept joint and several liability with the "junior" companies unless (a) they control the project, and (b) they are compensated in some manner for the value of their credit.

In a project finance arrangement it will be clear that no affluent party will be provid. ing credit (for which it will not receive compensation) to the party or parties of limited means, as each party will assume a proportionate share of the project finance loan obligations; and - as will usually be the case - if the parties of modest means are unable to provide the completion guarantees or other assurances the lender will require, the impoverished debtor must, at the possible risk of dilution of its interest, find another financial angel. Thus, one objective of the developers in arranging the project finance loan is that the credit standing of one party will not, in itself, help or hinder the others. 
A principal objective in securing project financing is to so limit recourse to the developer as not to affect its credit standing and, if possible, to relieve its balance sheet from an onerous burden of debt, particularly during the early life of the mine. Project financing is by its nature highly leveraged borrowing, with perhaps $80 \%$ or more of the capital requirements supplied by term indebtedness that is to be repaid as quickly as cash flow generated from the mine will permit. For companies that are used to a balance sheet showing term debt and shareholders' equity more or less in equilibrium, a substantial debt burden to place a large project into production could prove unacceptable to its bankers and general creditors, and may also contravene debt-to-equity ratio covenants contained in its general mortgage bonds.

The company can attempt to reduce the impact of these problems by the use of unconsolidated subsidiaries or associated corporations which are not affected by debt restrictions imposed upon the parent, but supported by the parent through the use of guarantees or other commitments ("off balance sheet financing") in support of the loans to the project.

\section{Project Financing: The Components}

\section{Viable Project}

Even with the guarantees that the lender will inevitably require, the developer must nonetheless produce a feasibility study of a quality acceptable to the financiers, evidenc. ing the viability of the project and its capability to service all debt required to place the property into production. If the feasibility study is prepared by the engineering department of the developer or another one of the "sponsors", the lender may very well require an analysis of and opinion on the study from a firm of independent engineers. It is important that the feasibility study deal with all aspects of the project and utilize assumptions - particularly tax and metal price assumptions - that are acceptable to the lender.

The viability of the project will also be tested by the lender's assessment of the mine management personnel employed by the developer and the expertise of the contractor who is to construct the project. The ley terms of the construction contract will be exam. ined by the lender and must be consistent with the anticipated capital requirements of the project.

\section{The Completion Guarantee}

Two different forms of guarantees are common in project financings: completion guarantees and deficiency guarantees. A completion guarantee is an assurance to the lender that funds will be provided sufficient to ensure that the project will be up and running at a sustained rate for a specified period of time. Completion guarantees are sometimes referred to as over-run guarantees, but the obligations of the completion guarantor, as will be seen, often extend to commitments more onerous than merely the financing of over-runs.

The deficiency guarantee normally comes into play when the project is "completed", and is an assurance to the lender of orderly payment of instalments on the indebtedness, and thereby transfers to the guarantor the burden of impairment of cash flow due to vagaries in the metal markets.

The term "completion" in the completion guarantee does not mean completion of construction. That is but one aspect of the definition. (Nor is a completion guarantee in any way similar to a performance bond. The lender may well wish the contractor to furnish the usual construction bonds, but they are of limited comfort to the lender, who will usually wish to be repaid and to have forgotten about its investment long before the developer and the surety company have finally resolved the extent of liability under the performance bond.) The definition of completion entails successful completion of a viable productive unit with proved efficiency and operating capability. 
The definition of completion will also specify: the time period in which a specified quantity of output shall have been produced, thus establishing that all running-in problems have been resolved and that there is orderly supply of inventory; the required qual. ity of such output, which will be important if the customer has rejection limits or significant penalties for deleterious substances, or if environmental protection agencies may restrict production in the event of quality deficiencies; the maximum permitted cost of producing such output, so that if the project is uneconomic without modifications, the completion guarantor will be obliged to introduce changes to the mill circuits before obtaining a discharge from his guarantee obligations; the required percentage of projected cash flow which must be attained; the maximum time period permitted in which to attain such cash flow; and the specified level of working capital required to be maintained. This last-mentioned provision will relate to working capital at "completion", not at start-up. If there is a long "pipeline" for the minerals to reach a foreign smelter before beneficiation and payment, the working capital requirements of the mill will increase substantially during the initial months of operation.

When does the completion guarantor's obligation arise? It is incorrect to assume that the londer will blithely make advances to the project as construction proceeds, even when it becomes apparent that the lender's advance of the loan will be insuficient to bring the property into production. Rather, at the time of each drawdown, engineers' certificates must be produced to indicate whother the project is still within budget. If any over-run is then contemplated, the completion guarantor will be obliged to make all advances required to cover contemplated over-runs before the lender permits any further drawdowns on its loan.

The basic rule in project financing is that the principal lender, which in Canada is usually a chartered bank, is the last in with loan funds and the first out! Money advances by the completion guarantor must be subordinated to all indebtedness to the senior lender. These subordinated lenders must resolve among themselves their respective priorities. Often a dispute will arise between the completion guarantor and the deficiency guarantor regarding the order of priorities and debt retirement applicable to their claims. For the completion guarantor it is argued that its moneys were advanced first, and at a time when the project was at greater risk, and that the obligations of the completion guarantor should thus be retired before payment of indebtedness to the deficiency guarantor. The latter will point out, however, that its moneys are in essence a replacement of the senior loan indebtedness, and are subrogated in all respects to that senior indebtedness and the security therefor. Usually the deficiency guarantor wins.

\section{The Deficiency Guarantee}

Once the project is in operation and turning out mineral product at an scceptable rate and cost, the completion guarantor will be discharged. The lender, thus bereft of the financial assurance that the project will work, must cast about for fresh assurance that the indebtedness will be paid. That comfort will come in the first place from a requirement that all - or nearly all - "available cash" be used to retire the senior debt. The project finance lender does not accept the proposition that the loan should be paid down in an orderly, but protracted, basis over the life of the mine. Rather, he will demand that virtually all available cash generated by the project should be applied to the retirement of the senior lender's advances, even if revenues far outstrip the scheduled rate of maturities set out in the loan agreement.

The rationale to the lender is that each shovelful of coal or each ounce of silver removed from the property makes the lender's security that much more fragile, as the mineral wealth in the ground is steadily depleted. The risk of exhaustion of ore reserves before all debt is retired must rest with the junior lenders and the shareholders, and not with the senior creditor. Accordingly, the project finance loan agreement will set out a schedule of maturities, which will in many cases be tailored to fit projected variations in rate of throughput in the mill, and consequently revenues. However the loan agreement will require the mandatory prepayment of instaiments whenever revenues, after provi- 
sion for all operating costs, tares and capital replacements, exceed the specified instalments of principal payments.

No matter how efficient the mine operation, however, if mineral prices drop dramatically, then unless the developer has been fortunate enough to negotiate sales contracts with floor prices unaffected by world market conditions, the developer and his nervous lender will see revenues drop below the threshold required to ensure repayment of the loan in accordance with scheduled maturities. To protect itself against this eventuality, the lender obtains from a strong financial credit an assurance - commonly called a deficiency guarantee - that funds will be available to meet the minimum scheduled maturities in the loan agreement.

Some of the considerations involved in settling the terms of the deficiency guarantee include the following. First, there must be a clear demarcation of the time when the deficiency guarantor first becomes liable, and when the completion guarantor ceases to be liable. In some cases the completion guarantor rather than the deficiency guarantor may be liable for interim instalments of interest, or initial maturities of principal if "completion" is long delayed. There may even be cases - such as the ITT pulp mill in Quebec where the project will nover operate at design capacity. In such a case will it be the completion guarantor or the deficiency guarantor who must ultimately assume the debt burden?

The second point for consideration is the question whether the deficiency guarantor. as payments are made by it from time to time, should receive additional, separate security for its advances, or whether it should content itself with subrogation to the rights of the senior creditor whose indebtedness it has refunded. Because senior lenders habitually do not like any participation by the guarantor in their security until they have been paid in full, the deficiency guarantor cannot normally acquire any effective new security interest, but rather must content itself with becoming subrogated to the position of the senior lender after the senior indebtedness is retired in full. The problem is, howover, that the senior lender will insist upon its right to deal with the security as it thinks fit, including the release of certain security to the company to permit its sale or other disposition, thereby placing in possible jeopardy the security which the deficiency guarantor ultimately hopes to obtain.

A third consideration is the question whether the deficiency guarantor should be responsible for instalments of debt service if the company has, in past profitable periods, prepaid a portion of the indebtedness so that on balance, at the time of the quarterly deficiency, the company has paid an aggregate amount in excess of the scheduled maturities. The company and its guarantor wish to have the reward of a breathing space where revenues in one quarter are sufficient to pay the instalments of principal due not only in that quarter but in, for example, the next two quarters. The recipient lender will normally treat the prepayment of those two quarters' instalments as payment of the last two instalments falling due, so that if, in the next quarter, market prices diop and cash flow is less than the specified principal instalment for that quarter, the deficiency guarantor will be liable for the shortfall.

A similar question that must be resolved in the negotiation of the deficiency guarantoe is whether the occurrence of any event other than payment in full of the amount guaranteed shall serve to discharge the guarantor. The deficiency guarantor may insist that if the senior lender permits substantial deviation from the feasibility study or sale of substantial assets, then it should be discharged.

Finally, it is not uncommon for the deficiency guarantee to specify the extent to which the guarantor itself must meet financial covenants, either imposed upon it (such as restrictions on its total indebtedness and guarantees) or upon the borrower (such as working capital maintenance tests). The extent to which the lender will seek to entwine the guarantor in the borrower's net of financial covenants will depend upon the relationship between the guarantor and the borrower. If the guarantor is an arm's length party, such as the customer, the guarantor will seek to disclaim responsibility for the financial 
management of the borrower. In the long run, however, it cannot escape the consequences of financial mismanagement.

\section{Sales Contracts}

The lender will require assurance that a market for the mineral product exists throughout the term of the loan, and further, that the market will produce revenues sufficient to service the debt. This assurance usually comes in the form of long-term sales contracts which, if not connected with a deficiency guarantee, will contain a "take-or-pay" obligation on the part of the buyer. Under a true "take-or-pay" obligation the buyer must make periodic payments for product over the life of the contract in certain amounts (which will be sufficient to service the debt and to pay operating costs of the project) whether or not materials to the minimum amount are supplied, and whether or not the buyer is in a position to take delivery. There will, of course, be provisions for catch-up deliveries of product paid for and not taken, but one may naturally assume that a buyer of minerals, in today's volatile markets, is reluctant to pay for a product which, at the time of payment, may not be available for delivery.

In those circumstances, the buyer would much prefer a "take-and-pay" contract, whereby it will be obliged to pay for all minerals actually produced and delivered to a point of delivery, but will not be obliged to make payments for product which the mine developer is unable to deliver. One need not point out the lender's preference.

Although cosl and some minerals may be sold under long-term contracts at fired prices, or prices that escalate according to inflation factors, most metallic minerals produced in Western Canada are sold for prices that will fluctuate with free world prices. That being the case, the lender may require an assurance from the buyer that if market prices drop below a threshold price required to meet the borrower's revenue needs, the customer will lend to the producer, on a subordinated basis, the difference between that threshold price and market price for the products. The buyer, of course, will wish socurity for any such support loans, and will also seek to negotiate some assurance that it will remain the buyer of production until such loans are repaid. The buyer must not be deluded, however, into thinking that its long-term contract will assure to it product sufficient to generate the revenues required to ultimately repay the subordinated loans. If the project fails before the senior lender has been repaid, the senior lender may, through its receiver, sell the entire mining undertaking to a third party that will take the project free of the sales contract commitments, leaving the customer with a claim in the borrower's bankruptcy and with no minerals.

\section{Participants in the Project}

As the above observations will indicate, the capital structure of a project will often prove complex, and many layers of the debt onion must be peeled off before the equity participant's interest materializes. The senior lender will never provide $100 \%$ of project financing. As a result, then, quite apart from the guarantees, the project developers or sponsors must make equity contributions or loans by way of unsecured subordinated ad. vances in some material amount, perhaps as much as 25 or $30 \%$ of the total project costs. Then cost over-runs or revenue deficiencies may result in additional loans - in this case from the guarantors. Other financial assistance, on a loan basis, may be provided by provincial development corporations or federal credit-granting institutions. In each case the order of advances, priority of claims against security and order of debt retirement must be resolved.

As to the developers of the project themselves, they must determine the form of their association. Under Canadian tax laws participants in mine development prefer to operate as joint ventures. In that way the very substantial write-offs available in the early years on account of exploration and development expenditures, and accelerated depreciation for certain capital plant, can be used to offet income earned during that period from other operations of the mine owners. By doing so, however, they relinquish some of the sdvantages that are available to those persons who participate in project development 
through a corporation in which each participant holds shares proportionate to its interest in the project. Those foregone advantages include the limited liability of shareholders, the unlimited existence of a corporation, the better clarification and centralization of management of the operation (instead of each joint venture participant contributing its management opinions), and the establishment of a clearly separate bargaining unit entity for labour relations matters.

The selection of the form of entity will also be affected by laws and regulations, domestic and foreign, which may restrict the nature of investment. It is not unusual for the foreign customer who will purchase the project's production to participate in the development and ownership of the project. But if that foreign entity's banking laws restrict the export of equity capital, the customer must somehow frame its participation as a loan while at the same time persuading its partners and the lender that it should be regarded as a contributor of equity.

The Foreign Investment Review Act ${ }^{15}$ produces problems all of its own in this field. Under that Act, if development of the project is by way of joint venture, the joint venturers will be considered a "group of persons" who are establishing a business in Canada. If any one of these persons is a "non-eligible person" within the meaning of the Act then the establishment of the project becomes a reviewable transaction. Thus the foreign customer who is cut in for a $10 \%$ participation in the joint venture may subject the development to the review process notwithstanding that the remaining $90 \%$ interests are all held by - to use the convoluted language of the Act - persons who are not non-eligible. In such a case, timing demands may well force the participants to convert their interests from a joint venture to a corporation, notwithstanding the tax aspects.

One cannot overlook the potential for conflicts of interest among the participants in the joint venture. The customer providing assistance to the project by means of take-0r-pay provisions in its contract, or supporting price loans to ensure minimum gross revenues to the producer, may not be greatly concerned over the profitability of the mining operations. If that customer provides its accommodation by means of a deficiency guarantee, however, the bottom line rather than the top line of the income statement will become more significant. If the customer holds an equity interest as well, then profitability becomes all the more important to it.

But in some cases the project is merely one aspect of an integrated operation for an owner who does not require a specified return on mining investment to justify the project's existence. The profits will be made at a further stage of refinement of the mineral, and away from the scrutiny of the co-owners. For others in the project, the mine is the end in itself and must demonstrate a satisfactory rate of return on its investment.

Additional problems may arise among the participants where one of them has already established mining operations in the area, and is thus able to make available infrastructure, transport or other amenities that will be useful for development of the project. The cost of participation and the extent to which participation may be over-ridden by the external demands of the supplier of those amenities involve careful negotiation.

If the property is to be placed into production on a project finance basis, the participants, no matter how disparate their objectives, must work together to settle among themselves and with the lenders a scheme of development which reflects the orderly financing of the project into production on a basis consistent with that contemplated in the feasibility study, and which provides for the retirement of the project loans out of an assured source of cash flow to be generated by the project. It must be remembered that just as the lenders will not be entitled to share in the added profits that will enure to the project when mineral reserves are (as so often is the case) demonstrated to exceed those defined in the feasibility study, so will the lender not wish to share in the risks of revenue

15. Supre n. 9. 
shortfalls. In each case, the benefits and burdens that prove Marshall's Generalized Iceberg Theorem ("Seven-eighths of everything can't be seen") must rest with the project developers.

\title{
VI. ENVIRONMENTAL CONSIDERATIONS
}

Once a decision has been made to place a mining property into commercial production, a multiplicity of statutes must be adhered to in obtaining permits which allow production to be undertaken. In British Columbia a typical list of permits, approvals and leases required to place a mining property into production on Crown land include the following:

PERMIT, APPROVAL OR LEASE
Mining Lease
Reclamation Permit
Approval of Mining Plan and
Operating Method
Tailings Dam and Water
Dam Approval
Water Usage Licenses and
Water Storage Permits
Water Diversion Approvals
Effluent Pollution Control Permit
Emission Pollution Control Permit
Refuse and Domestic Garbage
Pollution Control Permit
Special Use Permit
Plant Site and Tailings Pond
Land Lease

\author{
STATUTE \\ Mineral Act ${ }^{16}$ \\ Mining Regulation Act" \\ Mining Regulation Act \\ Mining Regulation Act \\ Water Act ${ }^{\text {10 }}$ \\ Water Act \\ Pollution Control Act'19 \\ Pollution Control Act \\ Pollution Control Act \\ Forests Act ${ }^{20}$ \\ Land Act ${ }^{23}$
}

An environmental impact study must be filed with the Ministry of Mines when making application for the above permits. That study may be commented on by any one of the following Government bodies:

Water Rights Branch, British Columbia Land Commission

Pollution Control Branch

Ministry of Highways and Public Works

Fish and Wildlife Branch

Land Management Branch

Department of Economic Development

Environmental and Land Use Commission, and

Department of Municipal Affairs.

All of the above departments and agencies must be satisfied. The Environment and Land Use Commission has power under the Environment and Land Use Act ${ }^{22}$ to call a public enquiry at any time if it feels that such an enquiry is necessary for the proper considera. tion of the application.

The assembly of documentation for the above permits, approvals and leases is largely a technical matter which is normally carried out by the company and not by the lawyers. The applications are prepared in the normal course by the company as it proceeds with its internal operations of designing the mining méthods, plant site, and tailings disposal

\footnotetext{
16. Supre n. 1.

17. R.S.B.C. 1979 , c. 265.

18. R.S.B.C. 1979 , c. 429.

19. R.S.B.C. 1979. c. 332

20. R.S.B.C. 1979, c. 140 .

21. R.S.B.C. 1979 , c. 214

22. R.S.B.C. 1979 , c. 110
} 
systems. Often all matters are carried on together, including the Environmental Impact Study. As a result, a company may not be able to file sequential documents particularly if each document will be related in one form or another to the other documents. It is not uncommon, then, for mine development to outstrip the receipt of necessary approvals, a course the company must adopt if it is to meet its financial timetable, but which is not without risk. But risk is an inherent feature of the mining industry.

\title{
APPENDIX “A”
}

\section{OPTION AGREEMENT}

THIS AGREEMENT made this day of June, 1980

\section{BETWEEN:}

\author{
GOLDEN TOUCH MINING LIMITED, a British \\ Columbia corporation having its head \\ office at 123 Granville Street, \\ Vancouver, British Columbia, \\ ("Golden Touch")
}

OF THE FIRST PART

AND:

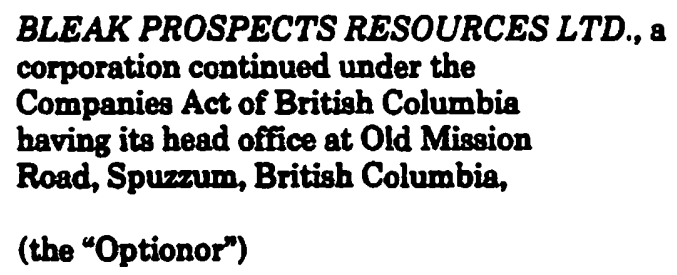

OF THE SECOND PART

\section{WHEREAS:}

(A) the Optionor is the owner of 32 mineral claims located under the Mineral Act of British Columbia located in the Atlin Mining Division;

(B) the Optionor has agreed to grant an exclusive option to Golden Touch to acquire all of the Optionor's interest in and to the Property, subject to the Royalty herein provided for, by performing work upon the Property and committing to place the same into commercial production, all as berein provided;

NOW THEREFORE THIS AGREEMIENT WITNESSES that in consideration of the sum of \$5,000 now paid by Golden Touch to the Optionor and for other good and valuable consideration, the receipt and sufficiency whereof is by the Optionor hereby ackenowlodged, the parties agree as follows:

\section{DEFINITIONS}

1. For the purposes of this Agreement the following words and phrases shall have the following meanings, namely:

(a) "Commencement of Commerical Production" means

(i) if a concentrator is located on the Property, the last day of a period of $\mathbf{4 0}$ consecutive days in which, for not less than 30 days, such concentrator processed ore from the Property at $60 \%$ of its rated concentrating capecity, or 
(ii) if no concentrator is located on the Property, the last day of the first period of 30 consecutive days during which ore has been shipped from the Property on a reasonably regular basis for the purpose of earning revenues;

but no period of time during which ore or concentrate is shipped from the Property for testing purposes, and no period of time during which milling operations are undertaken as initial tune-up, shall be taken into account in determining the date of Commencement of Commercial Production;

(b) "Gross Revenues" for any period means the revenue received by Golden Touch in that period from the sale of ores and concentrates produced from the Property (exclusive of any treatment, refining or other charges deducted by the smelter or refiner to whom the ore or concentrate is shipped);

(c) "Mill" meens the crusher, concentrator and other processing facilities to be constructed on or in proximity to the Property and to be used for the processing of production from the Property, whether or not in conjunction with or after production from any other mineral property;

(d) "Net Profits" for any year means the Gross Revenue received in that year less successively: all Operating Expenses incurred by Golden Touch during the year and any excess of Operating Bxpenses over Gross Revenues for all prior years to the extent that such excess has not been previously deducted in computing Net Profits;

(e) "Operating Expenses" means all costs, expenses, obligations, liabilities and charges of whatsoever kind or nature, including capital expenditures but excluding depreciation and amortization, incurred or chargeable by Golden Touch after Commencement of Commercial Production in connection with operations in the Mill and on the Property, including, without limiting the generality of the foregoing, all expenses in connection with mining, handling, processing, transporting and marketing of any ore or concentrates produced from the Property, an amount for interest on the balance of Preproduction Expenditures at the prime rate charged by the principal chartered bank of Golden Touch to its commercial customers from time to time plus 2\% per annum compounded annually on the 31st day of December in each year, and all coste of milling or other treatment facilities incurred in respect thereof, all tares and royalties (other than income tax unless all amounts of Royalty payable hereunder are not deductible in calculating taxable income on which income tax is payable) and other amounts paid to taxing and governmental authorities. There shall be included in Operating Expenses a reasonable charge by Golden Touch in respect of its head office overhead costs attributable to the Property, which shall not exceed (i) $71 / 2 \%$ of the foregoing costs and expenses, other than capital costs and expenses and interest on the balance of Preproduction Expenditures, (ii) $2 \frac{1}{2} \%$ of such of the foregoing costs, expenses, obligations and liabilities as constitute capital costs and expenses, and (iii) nil in respect of interest on the balance of Preproduction Expenditures;

(f) "Option" means the option to acquire all right, title and interest of the Optionor to and in the Property as provided in Section 4;

(g) "Option Period" means the period during the term of this Agreement from the date hereof to and including the date of exercise of the Option;

(h) "Preproduction Expenditures" means the sum of

(i) all costs of acquisition and maintenance of the Property, all exploration and development expenditures and all other costs and expenses of whatsoever kind or nature including those of a capital neture, incurred or chargeable prior to the date of Commencement of Commerical Production by Golden Touch with respect to the exploration and development of the Property and the placing of the Property into Commercial Production including such expenditures made by Golden Touch after January 1, 1980 but prior to the date of erecution hereof, (ii) as compensetion for general overheed expenses which Golden Touch will incur, an amount equal to (A) $10 \%$ of all amounts included in subparagraph (i) 
in each year except costs of fixed assets and costs and expenditures paid by Golden Touch under any contract involving payments by it in excess of $\$ 1,000,000$ in the year, and (B) $5 \%$ of all other amounts included in subparagraph (i) in each year, and

(iii) a carrying charge on the sum of the amounts included in subparagraphs (i) and (ii) at a rate equal to the prime rate charged by the principal chartered bank of Golden Touch to its commercial customers plus $2 \%$ per annum compounded annually on the 31st day of December in each year;

(i) "Production Commitment" means the commitment to place the Property into production given pursuant to Paragraph 5(a);

(j) "Property" means the mineral claims described in Schedule " $A$ " hereto, and all mining leases and other mining interests derived from any such claims. Any reference herein to any mineral claim comprised in the Property includes any mineral leases or other interests into which such mineral claim may have been converted;

(k) "Property Rights" means all licenses, permits, easements, rights-of-way, certificates and other approvals obtained by either of the parties either before or after the date of this Agreement and necessary for the development of the Property, or for the purpose of placing the Property into production or continuing production therefrom:

(l) "Royalty" means the amount of royalty from time to time payable to the Optionor hereunder after Commencement of Commercial Production pursuant to Section 10.

\section{REPRESENTATIONS AND WARRANTIES OF THE OPTIONOR}

2. (a) The Optionor represents and warrants to Golden Touch that:

(i) it has been duly continued under the Companies Act of British Columbia and validly exists as a corporation in good standing under the laws of British Columbia and is, under the laws of British Columbia legally entitled to hold the Property and all mineral claims comprised therein, and all Property Rights held by it and will remain so entitled until all interests of the Optionor in the Property (other than the Royalty) have been duly transferred to Golden Touch as contemplated hereby;

(ii) it is, and at the time of each transfer to Golden Touch of mineral claims comprising the Property it will be, the recorded holder and beneficial owner of all of the mineral claims comprising the Property free and clear of all liens, charges and claims of others and no tares or rentals are due in respect of any thereof; the mineral claims comprised in the Property have been duly and validly located and recorded pursuant to the Mineral Act of British Columbia, and, except as specified in Schedule " $A$ " hereto and accepted by Golden Touch, are in good standing in the office of the Mining Recorder on the date hereof and until the dates set opposite the respective names thereof in Schedule " $A$ " hereto; (iii) there is no adverse claim or challenge against or to the ownership of or title to any of the mineral claims comprising the Property, nor to the knowledge of the Optionor is there any basis therefor, and there are no outstending agreements or options to acquire or purchase the Property or any portion thereof, and no person other than the Optionor, pursuant to the provisions hereof, has any royalty or other interest whatsoever in production from any of the mineral claims comprising the Property;

(iv) it has duly obtained all corporate authorizations for the execution of this Agreement and for the performance of this Agreement by it, and the consummation of the transaction herein contemplated will not conflict with or result in any breach of any covenants or agreements contained in, or constitute a default under, or result in the creation of any encumbrance under the provisions of, the Articles or the constating documents of the Optionor or any shareholders' or directors' resolution, indenture, agreement or other instrument whatsoever to 
which the Optioner is a party or by which it is bound or to which it may be subject;

(v) no proceedings are pending for, and the Optionor is unaware of any basis for the institution of any proceedings leading to, the dissolution or winding up of the Optionor or the placing of the Optionor in bankruptcy or subject to any other laws governing the affairs of insolvent persons;

(vi) the Property is not the whole or substantially the whole of the undertaking of the Optionor.

(b) The representations and warranties contained in this Section are provided for the exclusive benefit of Golden Touch, and a breach of any one or more thereof may be waived by Golden Touch in whole or in part at any time without prejudice to its rights in respect of any other breach of the same or any other representation or warranty; and the representations and warranties contained in this Section shall survive the erecution hereof.

\section{REPRESENTATIONS AND WARRANTIES OF GOLDEN TOUCH}

3. (a) Golden Touch represents and warrants to the Optionor that it has been duly incorporated and validly exists as a corporation in good standing under the laws of British Columbia and is lawfully authorized to hold mineral claims and real property in the Province of British Columbia.

(b) Golden Touch represents and warrants to the Optionor that neither the execution and delivery of this Agreement by Western nor the performance by Golden Touch of its obligations hereunder obliges Golden Touch to give notice to the Foreign Investment Review Agency under the Foreign Investment Review Act.

(c) The representations and warranties contained in this Section 3 are provided for the exclusive benefit of the Optionor and a breach of any one or more thereof may be waived by the optionor in whole or in part at any time without prejudice to its rights in respect of any other breach of the same or any other representation or warranty; and the representations and warranties contained in this Section shall survive the execution bereof.

\section{ACQUISITION OF OPTION}

4. (a) The Optionor hereby grants to Golden Touch the sole and exclusive right and option, subject to the terms of this Agreement, to acquire the Property free and clear of all charges, encumbrances and claims, save and except for those set out herein.

(b) This Agreement and the Option shall terminate if prior to delivering the Production Commitment Golden Touch has failed to make any of the following Option payments at the time described:

(i) $\$ 100,000$ six months after the date hereof; and

(ii) $\$ 100,000$ on each anniversary of the date hereof until such time as Golden Touch has delivered the Production Commitment.

\section{EXERCISE OF OPTION}

5. (a) Golden Touch may at any time after it has expended in the aggregate $\$ 1,000,000$ on exploration and development expenses, including feasibility studies, on the Property, exercise the Option by delivering a notice to the Optionor containing Golden Touch's commitment to cause the Commencement of Commercial Production from the Property (the "Production Commitment"), which notice shall specify the number of tons of proven and probable ore reserves on the Property at the time estimated by Golden Touch and the anticipated annual rate of production therefrom as anticipated by Golden Touch, provided always that nothing herein shall at any time oblige Golden Touch to give such notice.

(b) If and when the Option has been exercised, a 100\% right, title and interest in and to the Property shall vest in Golden Touch free and clear of all charges, encum- 
brances and claims, save and except for the obligations of Golden Touch under Sections 10 and 13.

(c) After the Option has been exercised Golden Touch shall proceed without delay to place the Property into production and to supply or cause to be supplied financing required for the purpose subject always to Section 14 and to the right, which is hereby reserved to it, to vary the rate of production from that specified in the Production Commitment.

\section{RIGHT OF ENTRY}

6. Throughout the Option Period the Directors and Officers of Golden Touch and its servants, agents and independent contractors, shall have the sole and exclusive right in respect of the Property to

(a) enter thereon;

(b) have exclusive and quiet possession thereof;

(c) do such prospecting, exploration, development and/or other mining work thereon and thereunder as Golden Touch in its sole discretion may determine advisable;

(d) bring upon and erect upon the Property buildings, plant, machinery and equipment as Golden Touch may doem advisable; and

(e) remove therefrom and dispose of reasonable quantities of ores, minerals and metals for the purposes of obtaining assays or making other tests.

\section{TRANSFER OF PROPERTY}

7. (a) Concurrently with the execution of this Agreement the Optionor shall deliver to Golden Touch duly ezecuted transfers of the Property in favour of Golden Touch.

(b) Golden Touch shall be entitled to record all transfers contemplated hereby at its own cost with the appropriate government office to effect legal transfer of the Property into the name of Golden Touch, provided that Golden Touch shall hold the Property subject to the terms of this Afreement, it being understood that the tranafer of legal title to Golden Touch prior to the exercise of the Option is for administrative convenience only.

\section{OBLIGATIONS OF GOLDEN TOUCH DURING OPTION PERIOD}

8. During the Option Period Golden Touch shall:

- (a) maintain in good standing those mineral claims comprised in the Property that are in good standing on the date hereof by the doing and filing of assessment work or the making of payments in lieu thereof, by the payment of taxes and rentals and the performance of all other actions which may be necessary in that regard and in order to keep such mineral claims free and clear of all liens and other charges arising from Golden Touch's activities thereon except those at the time contested in good faith by Golden Touch;

(b) permit the directors, officers, employees and designated consultants of the Optionor, at their own risk, access to the Property at all reasonsble times subject always to Section 15, provided that the Optionor agrees to indemnify Golden Touch against and to save it harmless from all costs, claims, liabilities and expenses that Golden Touch may incur or suffer as a result of any injury (including injury causing death) to any director, officer, employee or designated consultant of the Optionor while on the Property;

(c) deliver to the Optionor on or before March 15 in each year a report (including up-to-date maps if there are any) describing the results of work done in the last completed calendar year, together with reasonable details of Preproduction Expenditures made;

(d) do all work on the Property in a good and workmanlike fashion and in accordance with all applicable laws, regulations, orders and ordinances of any governmental authority; 
(e) indemnify and save the Optionor harmless in respect of any and all costs, claims, liabilities and expenses arising out of Golden Touch's activities on the Property and, without limiting the generality of the foregoing shall, during the currency of this Agreement, carry not less than $\$ 5,000,000$ in third party liability insurance in respect of its operations on the Property for the benefit of Golden Touch and the Optionor as their interests appear; provided that Golden Touch shall incur no obligation hereunder in respect of claims arising or damages suffered after termination of the Option if upon termination of the Option any workings on or improvements to the Property made by Golden Touch are left in a safe condition;

(f) deliver to the Optionor forthwith after receipt by Golden Touch assay results for samples taken from the Property, together with reports showing the location from which the samples were taken and the type of samples.

\section{TERMINATION OF OPTION}

9. (a) If the Option is terminated otherwise than upon the exercise thereof pursuant to Paragraph 5(a), Golden Touch ahall:

(i) leave in good standing for a period of at least 90 days from the termination of the Option Period those mineral claims comprised in the Property that are in good standing on the date hereof and any other mineral claims comprised in the Property that Golden Touch brings into good standing after the date hereof;

(ii) deliver to the Optionor a Bill of Sale in recordable form whereby the right, title and interest in the Property has been transferred to the Optionor or its nominee or nominees, free and clear of all liens or charges arising from Golden Touch's activities on the Property;

(iii) deliver at no cost to the Optionor within 90 days of such termination copies of all reports, maps, assay results and other relevant technical data compiled by or in the possession of Golden Touch with respect to the Property and not theretofore furnished to the Optionor.

(b) Notwithstanding termination of the Option, Golden Touch shall have the right, within a period of 180 days following the end of the Option Period, to remove from the Property all buildings, plant, equipment, machinery, tools, appliances and supplies which have been brought upon the Property by or on behalf of Golden Touch, and any such property not removed within such 180-day period shall thereafter become the property of the Optionor.

\section{ROYALTY}

10. (a) For the first year in which aggregate Net Profits for that year and all prior years exceeds Preproduction Expenditures, the Optionor shall be paid a royalty equal to $20 \%$ of such excess, and for each year thereafter the Optionor shall be paid an annual Royalty equal to $20 \%$ of Net Profits, if any, for that year.

(b) Instalments of Royalty payable under Paragraph (a) shall be paid by Golden Touch as follows:

(i) within 15 days after the end of each of the first 3 calendar quarters in each year and within 25 days of the end of the last calendar quarter in each year, Golden Touch shall pay to the Optionor an amount equal to $25 \%$ of the estimated Royalty, if any, for the year, and

(ii) on or before March 31st in each year the balance, if any, of Royalty payable in respect of the year last completed.

(c) After Commencement of Commercial Production, Golden Touch shall, within 30 days after the end of each calendar quarter, furnish to the Optionor quarterly unaudited statements respecting operations on the Property, together with a statement of Net Profits for the quarter last completed.

(d) Forthwith after the end of each calendar year commencing with the year in which Commencement of Commercial Production occurs, the accounts of Golden Touch related to operations on the Property shall be audited by the auditors of 
Golden Touch, and the statement of operations, which shall include the statement of Net Profits for the year last completed and, until Royalty first becomes payable hereunder a statement of Preproduction Expenditures and aggregate Net Profits, shall be furnished to the Optionor not later than March 31 in each year. The Optionor shall have $\mathbf{4 5}$ days after receipt of such statements to question the accuracy thereof in writing and, failing such objection, the statements shall be deemed to be correct and unimpeachable thereafter.

(e) If the audited financial statements furnished pursuant to Paragraph (d) disclose any overpayment of Royalty by Golden Touch during the year, the amount of the overpayment shall be debited against future instalments of Royalty payable hereunder or shall, if requested by Golden Touch, be refunded by the Optionor forthwith.

\section{POWER TO CHARGE PROPERTY}

11. At any time after Golden Touch has exercised the Option, Golden Touch may grant mortgages, charges or liens (each of which is herein called a "mortgage") of and upon the Property or any portion thereof, any mill or other fixed assets located thereon, and any or all of the tangible personal property located on or used in connection with the Property to secure financing of development of the Property, provided that, unless otherwise agreed to by the Optionor it shall be a term of each mortgage that the mortgagee or any person acquiring title to the Property upon enforcement of the mortgage shall hold the same subject to the rights of the Optionor hereunder as if the mortgagee or any such person had executed this Agreement as party of the first part.

\section{TRANSFERS}

12. (a) Golden Touch may at any time either during the Option Period or thereafter, sell, transfer or otherwise dispose of all or any portion of its interest in and to the Property and this Agreement provided that any purchaser, grantee or transferee of any such interest shall have first delivered to the Optionor its agreement related to this Agreement and to the Property, containing:

(i) a covenant by such transferee to perform all the obligations of Golden Touch to be performed under this Agreement in respect of the interest to be acquired by it from Golden Touch to the same extent as if this Agreement had been originally executed by Golden Touch and such transferee as joint and several obligors making joint and several covenants; and

(ii) a provision subjecting any further sale, transfer or other disposition of such interest in the Property and this Agreement or any portion thereof to the restrictions contained in this Paragraph (a).

(b) No assignment by Golden Touch of any interest less than its entire interest in this Agroement and in the Property shall, as between Golden Touch and the Optionor, discharge it from any of its obligations hereunder, but upon the transfer by Golden Touch of the entire interest at the time held by it in this Agreement (whether to one or more transferees and whether in one or in a number of successive transfers), Golden Touch shall be deemed to be discharged from all obligations hereunder save and except for the payment of the Royalty or other fulfillment of contractual commitrients accrued due prior to the date on which Golden Touch shall have no further interest in this Agreement.

(c) If the Optionor should receive a bona fide offer from an independent third party (the "Proposed Purchaser") dealing at arm's length with the Optionor to purchase all or substantially all of its interest in the Property, which offer the Optionor desires to accept, or if the Optionor intends to sell all or substantially all of its interest in the Property, the Optionor shall first offer (the "Offer") such interest in writing to Golden Touch upon terms no less favourable than those offered by the Proposed Purchaser or intended to be offered by the Optionor, as the case may be. 
The Offer shall specify the price and terms and conditions of such sale, the name of the Proposed Purchaser (which term shall, in the case of an intended offer by the Optionor, mean the person or persons to whom the Optionor intends to offer its interest) and, if the offer received by the Optionor from the Proposed Purcheser pro. vides for any consideration payable to the Optionor otherwise than in cash, the Offer shall include the Optionor's good faith estimate of the cash equivalent of the non-cash consideration. If within a period of 60 days of the receipt of the Offer Golden Touch notifies the Optionor in writing that it will accept the same, the Optionor shall be bound to sell such interest to Golden Touch (subject as hereinafter provided with respect to price) on the terms and conditions of the Offer. If the Offer so accepted by Golden Touch contains the Optionor's good faith estimate of the cash equivalent consideration as aforesaid, and if Golden Touch disagrees with the Optionor's best estimate, Golden Touch shall so notify the Optionor at the time of acceptance and Golden Touch shall, in such notice, specify what it considers, in good faith, the fair cash equivalent to be and the resulting total purchase price. If Golden Touch so notifies the Optionor, the acceptance by Golden Touch shall be effective and binding upon the Optionor and Golden Touch and the cash equivalent of any such non-cash consideration shall be determined by binding arbitration under the Arbitration Act of British Columbia and shall be payable by Golden Touch, subject to prepayment as hereinafter provided, within 60 days following its determination by arbitration. Golden Touch shall in such case pay to the Optionor, against receipt of an absolute transfer of clear and unencumbered title to the interest of the Optionor being sold, the total purchase price which is specified in its notice to the Optionor and such amount shall be credited to the amount determined following arbitration of the cash equivalent of any non-cash consideration. If Golden Touch fails to notify the Optionor before the expiration of the time limited therefor that it will purchase the interest offered, the Optionor may sell and transfer such interest to the Proposed Purchaser at the price and on the terms and conditions specified in the Offer for a period of 60 days, provided that the terms of this paragraph shall again apply to such interest if the sale to the Proposed Purchaser is not completed within the said 60 days. Any sale hereunder shall be conditional upon the Proposed Purchaser delivering a written undertaking to Golden Touch, in form and substance satisfactory to its counsel, to be bound by the terms and conditions of this Agreement.

\section{SURRENDER AND ACQUISITION OF PROPERTY INTERESTS \\ PRIOR TO TERMINATION OF AGREEMENT}

13. Golden Touch may at any time either before or after the Commencement of Commercial Production, elect to abandon any one or more of the mineral claims comprised in the Property by giving notice to the Optionor of such intention. For a period of $\mathbf{3 0}$ days after the date of delivery of such notice the Optionor may elect to have any or all of the mineral claims in respect of which such notice has been given transferred to it by delivery of a request therefor to Golden Touch, whereupon Golden Touch shall deliver to the Optionor a Bill of Sale or other appropriate Deed or assurance in registrable form transferring such mineral claims to the Optionor. Any claims so transferred,.if in good standing at the date hereof or if Golden Touch causes the same to be placed in good standing after the date hereof, shall be in good standing under the Mineral Act for at least 90 days from the date of transfer. If the Optionor fails to make request for the transfer of any mineral claims as aforesaid within such 30-day period, Golden Touch may then abandon such mineral claim without further notice to the Optionor. Upon any such transfer or abandonment the mineral claims so transferred or abandoned shall for all purposes of this Agreement cease to form part of the Property.

14. (a) If Golden Touch is at any time either during the Option Period or thereafter 
prevented or delayed in complying with any provisions of this Agreement by reason of strikes, walk-outs, labour shortages, power shortages, fuel shortages, fires, wars, acts of God, governmental regulations restricting normal operations, shipping delays or any other reason or reasons beyond the control of Golden Touch, the time limited for the performance by Golden Touch of its obligations hereunder shall be extended by a period of time equal in length to the period of each such prevention or delay, provided however that nothing herein shall discharge Golden Touch from its obliga. tions under Paragraph 8(a).

(b) Golden Touch shall within 7 days give notice to the Optionor of each event of force majeure under Paragraph (a) and upon cessation of such event shall furnish the Optionor with notice to that effect together with particulars of the number of days by which the obligations of Golden Touch hereunder have been extended by virtue of such event of force majeure and all preceding events of force majeure.

(c) After the Commencement of Commercial Production, Golden Touch shall work, mine and operate the Property during such time or times as Golden Touch in its sole judgment considers such operations to be profitable. Golden Touch may suspend or curtail operations (both before and after Commencement of Commercial Production) during periods when the products derived from the Property cannot be profitably sold at prevailing prices or if an unreasonable inventory thereof, in Golden Touch's sole judgment, has accumulated or would otherwise accumulate.

\section{CONFIDENTIAL INFORMATION}

15. No information furnished by Golden Touch to the Optionor hereunder in respect of the activities carried out on the Property by Golden Touch, or related to the sale of product derived from the Property, shall be published by the Optionor without the prior written consent of Golden Touch, but such consent in respect of the reporting of factual data shall not be unreasonably withheld, and shall not be withheld in respect of information required to be publicly disclosed pursuant to applicable securities or corporation laws.

\section{ARBITRATION}

16. (a) The parties agree that all questions or matters in dispute with respect to the accounting of moneys expended by Golden Touch as provided herein, or with respect to the calculation of or amounts taken into account in the determination of Operating Expenses, Preproduction Expenses and Net Profits shall be submitted to arbitration pursuant to the terms hereof.

(b) It shall be a condition precedent to the right of any party to submit any matter to arbitration pursuant to the provisions hereof, that any party intending to refer any matter to arbitration shall have given not less than 10 days' prior written notice of its intention 80 to do to the other party together with particulars of the matter in dispute. On the expiration of such 10 days, the party who gave such notice may proceed to refer the dispute to arbitration as provided in Paragraph (c).

(c) The party desiring arbitration shall appoint one arbitrator, and shall notify the other party of such appointment, and the other party shall, within 15 days after receiving such notice, appoint an arbitrator, and the two arbitrators 80 named, before proceeding to act, shall, within 30 days of the appointment of the last appointed arbitrator, unanimously agree on the appointment of a third arbitrator to act with them and be chairman of the arbitration herein provided for. If the other party shall fail to appoint an arbitrator within 15 days after receiving notice of the appointment of the first arbitrator, the first arbitrator shall be the only arbitrator, and if the two arbitrators appointed by the parties shall be unable to agree on the appointment of the chairman, the chairman shall be appointed under the provisions of the Arbitration Act of British Columbia. Except as specifically otherwise provided in this section, the arbitration herein provided for shall be conducted in accordance with such 
Act. The chairman, or in the case where only one arbitrator is appointed, the single arbitrator, shall fix a time and place in Vancouver, British Columbia, for the purpose of hearing the evidence and representations of the parties, and he shall preside over the arbitration and determine all questions of procedures not provided for under such Act or this Section. After hearing any evidence and representations that the parties may submit, the single arbitrator, or the arbitrators, as the case may be, shall make an award and reduce the same to writing, and deliver one copy thereof to each of the parties. The expense of the arbitration shall be paid as specified in the award.

(d) The parties agree that the award of a majority of the arbitrators, or in the case of a aingle arbitrator, of such arbitrator, shall be final and binding upon each of them.

\section{DEFAULT AND TERMINATION}

17. (a) Notwithstanding Section 4, if at any time during the Option Period Golden Touch fails to perform any obligation required to be performed hereunder or is in breach of a warranty given herein, which failure or breach materially interferes with the implementation of this Agreement, the Optionor may terminate this Agreement but only if:

(i) it shall have first given to Golden Touch a notice of default containing par. ticulars of the obligation which Golden Touch has not performed, or the warranty bresched; and

(ii) Golden Touch has not, within 30 days following delivery of such notice of default, cured such default or commenced proceedings to cure such default by appropriate payment or performance (Golden Touch hereby agreeing that should it so commence to cure any default it will prosecute the same to completion without undue delay).

Should Golden Touch fail to comply with the provisions of subparagraph (ii) the Optionor may thereafter terminate this Agreement, and the provisions of Section 9 shall then be applicable.

(b) Golden Touch may permanently discontinue mining operations on the Property at any time after the Commencement of Commercial Production when in its opinion no further mining operations can be economically carried out thereon. At such time Golden Touch shall sell or otherwise dispose of all mining plant and equipment used pn the Property, effect all reclamation work as required by law, and sell or otherwise dispose of the Property as it thinks fit. Any purchaser of the Property after termination of mining operations shall take the same free of all claims of the Optionor, provided that all amounts received by Golden Touch in respect or any such sale of the Property shall be taken into account as Gross Revenue. The accounts of Golden Touch relating to the termination of mining operations on the Property shall be audited by the auditors of Golden Touch as soon as practicable after the sale or disposition of all mining plant and equipment and the Property and completion of reclamation. Final settlement of any Royalty payable to the Optionor shall be effected without delay after receipt of the final audit determination of Net Profits. After receipt of such final audit determination and payment of Royalty, if any, this Agreement and the mutual obligations of Golden Touch and the Optionor hereunder shall terminate.

(c) Golden Touch may retain for its other mining operations any plant or equipment used on the Property and no longer required for operations on the Property, provided that the value of any such plant or equipment shall be determined by an independent valuator acceptable to Golden Touch and the Optionor, or failing agreement on the choice of valuator, by a valuator to be selected by the auditors of Golden Touch, and the value of any such plant or equipment retained by Golden Touch shall be included in Gross Revenues. 


\section{NOTICES}

18. (a) Each notice, demand or other communication required or permitted to be given under this Agreement shall be in writing and shall be sent by prepaid registered mail deposited in a Post Office in Canada addressed to the party entitled to receive the same, or delivered to such party, at the address for such party specified above, in each case directed to the attention of the Secretary. The date of receipt of such notice, demand or other communication shall be the date of delivery thereof if delivered, or, if given by registered mail as aforesaid, shall be deemed conclusively to be the third day after the same shall have been 80 mailed except in the case of interruption of postal services for any resson whatever, in which case the date of receipt shall be the date on which the notice, demand or other communication is actually received by the addressee.

(b) Either party may at any time and from time to time notify the other party in writing of a change of address and the new address to which notice shall be given to it thereafter until further change.

\section{GENERAL}

19. (a) This Agreement shall supersede and replace any other agreement or arrangement, whether oral or written, heretofore existing between the parties in respect of the subject matter of this Agreement.

(b) No consent or waiver expressed or implied by either party in respect of any breach or default by the other in the performance by such other of its obligations hereunder shall be deemed or construed to be a consent to or a waiver of any other breach or default.

(c) The parties shall promptly execute or cause to be executed all documents, deeds, conveyances and other instruments of further assurance which may be reasonably necessary or advisable to carry out fully the intent of this Agreement or to record wherever appropriate the respective interests from time to time of the parties in the Property.

(d) This Agreement shall enure to the benefit of and be binding upon the parties and their respective successors and permitted assigns.

IN WITNESS WHEREOF the corporate seals of the Optionor and Golden Touch have been hereunto affixed in the presence of their duly authorized officers in that behalf.

THE CORPORATE SEAL OF GOLDEN TOUCH

MINING LIMITED was hereunto affixed

in the presence of:

THE CORPORATE SEAL OF BLEAK

PROSPECTS RESOURCES LTD. was

hereunto affired in the presence of: 


\title{
APPENDIX "B"
}

\section{JOINT VENTURE AGREEMENT}

\section{PRUDENT TOUCH JOINT VENTURE}

\author{
THIS AGREEMENT made the \\ day of June, 1980
}

\section{BETWEEN:}

\author{
GOLDEN TOUCH MINING LIMITED, a British \\ Columbia corporation having its head \\ office at 123 Granville Street, \\ Vancouver, British Columbia, \\ ("Golden Touch")
}

OF THE FIRST PART

AND:

\author{
PRUDENT EXPLORATIONS LTD., a British \\ Columbia corporation having its head \\ office at 2635 Howe Street, Vancouver, \\ British Columbia, \\ ("Prudent")
}

OF THE SECOND PART

\section{WHEREAS:}

(A) by agreement dated the 5th day of June, 1980 between Salted Mines Limited, as Optionor, and the Parties hereto, collectively as Optionee, the Parties have acquired from Salted Mines Limited an option to acquire the entire interest of Salted Mines Limited in and to the Property, subject to the Net Profits Interest therein provided for;

(B) the Parties intend to associate together as a joint venture, to be called the Prudent Touch Joint Venture, to perform the work required to be performed by them under the Option Agreement, and to hold and develop the Property as tenants in common, all upon the terms herein provided;

NOW THEREFORE THIS AGREEMENT WITNESSES that in consideration of the premises and the mutual covenants and agreements hereinafter contained the Parties hereto agree as follows:

\section{SECTION 1 - DEFINITIONS}

In this Agreement:

(a) "Approved Development Program" is a program of Development Work based on a feasibility study approved in accordance with Paragraph 9(d);

(b) "Approved Exploration Program" is the plans and budget established in accordance with Paragraphs 2(b) or 6(c);

(c) "Area of Interest" has the meaning assigned in Paragraph 18(a);

(d) "Cost Share" means the share of the Joint Venture Expense to be borne by each Participant and shall, after Joint Venture Expenses exceed $\$ 1,000,000$, be equal to the Participating Interest of such Participant; 
(e) "Development Work" means all work necessary, expedient or desirable for further exploration of any deposit of minerals to develop the same and to bring the same into commercial production, including the construction and installation of all buildings, plant and equipment required for commercial production of Product therefrom, but in no case shall "Development Work" include any work done prior to the establishment of an Approved Development Program;

(f) "Exploration Work" means all prospecting, ground and airborne geographical and radio-metric work, geochemical surveys, diamond and percussion drilling, bulldozing, trenching and other work commonly regarded as exploration work in accordance with good mining practice, but in no case shall "Exploration Work" include any work done subsequent to the establishment of an Approved Development Program;

(g) "Joint Venture" means the relationship among the Participants established under Paragraph 2(a);

(h) "Joint Venture Assets" means:

(i) all interests of the Participants in the Property;

(ii) all easements and other rights appurtenant to Program Lands;

(iii) all rights, data and other assets, tangible or intangible, acquired or developed in respect of the exploration or exploitation of the Property, including all water rights, pollution permits and similar licences obtained in respect of development of the Property, any feasibility study prepared at Joint Venture Expense under Section 9 and all technology, geological and geophysical data, reports and other data developed with respect to the Property;

(iv) all improvements to the Property, all fixtures, machinery, equipment and supplies and any other properties or rights of any description, whether real, personal or mixed, acquired at Joint Venture Expense pursuant to this Agreement;

(v) all interests of the Parties in the Option Agreement;

(vi) all Product; and

(vii) all proceeds accruing from the sale of the Property except the proceeds of the sale of Product;

(i) "Joint Venture Expense" means

(i) all charges incurred for Programs;

(ii) the Operator's fee and related costs herein provided for; and

(iii) payments under the Option Agreement other than in respect of Salted Net Profits Distribution;

(j) "Management Committee" means the Committee made up of representatives of the Participants as provided in Section 3;

(k) "Operating Year" means a period commencing on January 1 of a year and ending on December 31 of the same year;

(l) "Operator" means the person duly appointed to the position of Operator under Section 4 when acting in that capacity;

(m) "Option Agreement" means that agreement made the 5th day of June, 1980 between Salted Mines Limited, as Optionor, and the Participants, as Optionee, providing for the grant to the Participants of an option to acquire the Property;

(n) "Participant" means each of Prudent and Golden Touch so long as it holds a Participating Interest, and includes any other person who acquires a Participating Interest under Paragraph 7(c) so long as it holds a Participating Interest;

(o) "Participating Interest" means the percentage share which each Participant has from time to time in the Joint Venture Assets;

(p) "Party" or "Parties" means the parties to this Agreement and their respective permitted successors and assigns;

(q) "Product" means the end result of Production from the Property prior to the Participants having the right to take possession of their respective shares of the same (and, where the context requires, thereafter); 
(r) "Production" means mining, extracting, processing and handling the ores or minerals or concentrates derived therefrom which are discovered and developed on or in the Property and all other work related thereto as may be incidental or reasonably required;

(s) "Program" means the activities involved in the carrying out of an Approved Exploration Program, Approved Development Program or Production;

(t) "Property" means the mineral claims listed in Schedule " $A$ ", and includes the minoral dispositions (if any) becoming subject to this Agreement under Paragraph 18(a), and includes any mineral leases or other interests into which such mineral claims or dispositions may be converted;

(u) "Salted Net Profits Distribution" means the participation in net profits from the Property payable under the Option Agreement for which the Participants are liable as provided in Paragraph 10(e);

(v) unless there is something in the subject matter or context inconsistent therewith

(i) the singular shall include the plural and the plural shall include the singular,

(ii) the masculine shall include the feminine, and

(iii) a reference to any statute shall be deemed to extend to and include any amendment or re-ensctment of such statute.

\section{SECTION 2 - OBJECTIVES OF PARTICIPANTS}

(a) Establishment of Joint Venture and Relationship of Participants

The Participants hereby establish a Joint Venture for the purpose of exploring the Property and, if warranted by the results achieved from time to time, carrying out further Exploration Work and Development Work and Production from the Property. The relationship of the Participants is more particularly described in Section 11.

\section{(b) Initial Approved Exploration Program}

The plans and budget in the amount of $\$ 400,000$ set out in Schedule "B" are hereby established as an Approved Exploration Program for the 1980 Operating Year. Each Participant hereby irrevocably accepts such Approved Exploration Program.

\section{(c) Subsequent Program}

The Participants shall conduct further Exploration Work, Development Work, or Production for the acquisition of minerals by way of Programs as hereinafter provided.

\section{(d) Interest of the Participants}

The Participating Interest of each Participant until changed as herein provided is, for Golden Touch $70 \%$ and for Prudent $30 \%$, but until Joint Venture Expenses aggregate $\$ 1,000,000$ the Cost Shares for each Program shall be $\mathbf{9 0 \%}$ for Golden Touch and $10 \%$ for Prudent. The participation of each Participant in Programs and their respective interests in all Joint Venture Assets may from time to time be adjusted as provided in Sections 6 and 9.

\section{(e) Encumbrance of Property}

Until Joint Venture Expenses aggregate $\$ 1,000,000$ no Participant may mortgage, charge or otherwise encumber its Perticipating Interest. Thereafter, any Participant may mortgage, charge or otherwise encumber the whole or any other lesser undivided portion of its Participating Interest solely for the purpose of financing payment or performance of such Participant's obligations under this Agreement but only upon condition that the holder of such encumbrance (the "Chargee") shall have first entered into an agreement with the other Participants, in form reasonably satisfactory to counsel for such other Participants, binding upon the Chargee to the effect that:

(i) the Chargee will not enter into possession of, nor. institute any proceedings for partition or foreclosure of, the encumbered Participating Interest and that such encumbrance shall be subject to the provisions of this Agreement; and 
(ii) the Chargee's remedies under the encumbrance shall be limited to the sale of the whole (but only of the whole) of the encumbered Participating Interest in accordance with Paragraph 7(c) 83 if the Chargee were the Participant making the sale under that Paragraph.

\section{SECTION 3 - MANAGEMENT OF OPERATIONS}

(a) Management Committee

The affairs of the Joint Venture shall be under the direction and control of the Management Committee which shall be regulated as follows:

(i) The Management Committee shall consist of one representative of each Participant, and one representative of the Operator, if the Operator is not a Participant. Each Party entitled to representation shall have unrestricted discretion in the appointment of such representatives and their alternates or substitutes whose names shall be furnished to all other Parties, and who shall continue to serve until replaced by notice. The representative of the Operator shall act as chairman of the Management Committoe.

(ii) Meetings of the Management Committee shall be held in Vancouver, British Columbia, unless the Management Committee agrees otherwise. The Management Committee shall meet not less often then twice in each calendar year at such time as it may agree upon and shall also meet when called by any Participant upon not less than 10 nor more than 35 clear days' notice (unless such notice is waived by all the Participants).

(iii) A quorum of the Management Committee shall consist of one representative from each Participant. The Management Committee shall take no action without a quorum being present, provided that if a quorum is not present at the time and place set for a meeting, then the meeting may be adjourned to the same place at a time no fewer than 7 nor more than 21 days later and if notice of such adjournment is communicated to all the Participants, then on the adjourned date the Management Committee may proceed to conduct business without a quorum being present.

(iv) Unless otherwise provided in this Agreement a decision or action by the Management Committee shall require the concurrence of representatives holding more than 50\% of the Participating Interests.

(v) The chairman of the Management Committee may act on all other matters requiring Management Committee approval under the terms of this Agreement by the Management Committee approving the same in writing signed by the representatives of all of the Participants whether the Management Committee meets or not, and it shall be sufficient if the chairman of the Management Committee receives the approval of each Participant by telex or telegraph.

(vi) Minutes of each Management Committee meeting shall be prepared by the Operator with copies made available to the Participants within a period of 14 days after the meeting. Each Participant shall notify all other Participants of its approval or disapproval thereof in writing within 35 days of receipt of the same, failing which it shall be deemed to have approved the minutes.

(vii) The Management Committee may make additional rules for the conduct of its business which are not inconsistent with this Agreement.

(viii) The Operator shall not, in its capacity as Operator, have a vote on any matter to be determined by the Management Committee.

(b) Responsibilities of Management Committee

The Management Committee shall be responsible for the management and control of the affairs of the Joint Venture and in particular, but without limiting the generality of the foregoing, the Management Committee:

(i) shall first approve every Program, except the Approved Exploration Program approved pursuant to Paragraph 2(b), and the plans and budget therefor, and every alteration thereof, before the same is undertaken or effected; 
(ii) shall review and report on the statements provided by the Operator under subparagraph 5(a)(xv);

(iii) shall first approve the terms of any purchase or rental by or on behalf of the Joint Venture of equipment or other property from any Party or any affiliate or associate (as such terms are defined in the Companies Act) of any Party, provided that any such approval requires the affirmative vote of a majority of the Participating Interests of the Participants who are not associated or affiliated with either party to any such purchase or rental agreement;

(iv) shall first approve any contract to be entered into by or on bebalf of the Joint Venture involving the expenditure of more than $\$ 25,000$;

(v) shall first approve any proposed disposition by or on behalf of the Joint Venture of equipment or other property having either an original cost or market value in excesss of $\$ 25,000$;

(vi) shall first approve the appointment of any replacement or successor Operator under Paragraph 4(b) or 4(d);

(vii) shall first approve the abandonment or disposition of any part of the Property;

(viii) shall make all necessary determinations for the exercise, extension or cancellation of the Option granted under the Option Agreement; and

(ix) shall determine the manner in which, and by whom, any legel procoedings by or against the Joint Venture, or involving any Joint Venture Assets, should be conducted.

\section{SECTION 4 - OPERATOR}

\section{(a) General}

The Operator and its duly appointed successor shall have the powers, rights and responsibilities conferred upon it by this Agreement. Initially the Operator shall be Prudent.

\section{(b) Resignation of Operator}

The Operator may, by notice in writing to all Participants, resign at any time. An Operator that resigns shall not be released from its obligations hereunder as Operator for a period of 90 days after its resignation unless a successor Operator shall have been appointed and shall have arranged to assume the duties of Operator prior to the expiration of such period.

\section{(c) Termination of Operator's Appointment}

(i) The Operator's appointment may be terminated at any time upon 90 days' prior notice in writing from the Management Committee.

(ii) If the Operator fails to perform in a manner that is consistent with good mining practice, or fails to perform in a manner consistent with its duties and responsibilities under this Agreement, then the Management Committee may give to the Operator written notice setting forth particulars of the Operator's default. The Operator shall within $\mathbf{3 0}$ days of receipt of such notice commence to remedy the default. Failure of the Operator to commence to remedy the default within such 30-day period (and thereafter to proceed continuously and diligently to complete all required remedial action) shall be grounds for termination of the Operator's appointment.

(iii) The Management Committee shall have the right to replace the Operator forthwith by written notice to the Operator upon the occurrence of any of the following events:

(A) if an attachment is made on the Property which is not related to the business of the Joint Venture, but is in fact due to the negligence or omission of the Operator;

(B) if the Operator admits in writing its inability to pay its debts as they become due; or makes an assignment for the benefit of creditors, or consents to the 
appointment of a receiver for all or a substantial part of its property; or files a petition in bankruptcy or for a reorganization or an arrangement under the Bankruptcy Act, or otherwise seelss the relief therein provided; or is adjudicated bankrupt or insolvent; or

(C) if a Court order is entered in respect to the Operator appointing a receiver or trustee for all or a substantial part of its property, or approving a petition in bankruptcy or for a reorganization under the Bankruptcy Act or for any other judicial modification or alteration of the rights of creditors, which order is not vacated, set aside or stayed within 90 days of the date of entry.

\section{(d) Appointment of New Operator}

Upon the Operator's resignation or upon the termination of the Operator's appointment, the Management Committee shall appoint a new Operator.

(e) Operator's Fee

(i) The Operator shall be paid a fee of $\$ 36,000$ for its services from the date hereof to December 31, 1980. Thereafter the Operator's fee shall be in such amount as the Management Committee may approve and may include an amount in respect of general administrative costs that cannot be specifically allocable to the Joint Venture.

(ii) The Operator shall be reimbursed for all proper direct charges, expenses and other outlays made by it in the performance of its duties hereunder.

(iii) The Management Committee at any time may, and shall upon request of the Operator, adopt an accounting procedure and schedule of cost determinations to be utilized by the Operator for the determination of its charges and compensation horeunder.

(f) Transfer of Property

(i) Upon ceasing to be Operator, the Operator shall forthwith deliver to its successor, or to any other person nominated for such purpose by the Management Com. mittee, the custody of all assets, books, records and othor property both real and personal having to do with this Asreement. The former Operator shall use its best efforts to tranefer to its successor, effective 83 of the date of the former Operator's resignation or removal, its rights and obligations as Operator under all contracts relating to the Joint Venture operation, and pending such transfer and in relation to all other contracts relating to such operations, the former Operator shall hold its right and interest as Operator from the date of resignation or removal for the account and to the order of the new Operator.

(ii) As soon as practicable after the effective date of resignation or removal of the Operator, the Participants shall have the accounts of the Joint Venture audited by an independent auditor (who may be the auditor of a Participant), and shall conduct an inventory of all Joint Venture Property and such inventory shall be used in the return of and the accounting for the Joint Venture Property by the Operator who has resigned or has been removed. All costs and expenses incurred in connection with such audit and inventory shall be a Joint Venture Exponse.

\section{SECTION 5 - RESPONSIBILITIES OF OPERATOR}

(a) General

The Operator shall, subject always to the control and direction of the Management Committee at Joint Venture Expense:

(i) for any subsequent Program under Paragraph 2(c), submit to the Participants prior to October 31 in each year draft plans for the next ensuing Operating Year outlining its proposed activities and a draft budget including a breakdown of categories of expenditures for such Operating Year, together with an initial report of the results of prior work; 
(ii) for any subsequent Program under Paragraph 2(c), submit to the Participants prior to December 31 in each year detailed draft plans and budget for the proposed activities for the nert ensuing Operating Year, together with a detailed report of the results of prior work, and including such conclusions and detailed recommendations as the Operator deems warranted;

(iii) diligently and prudently conduct all operations in accordance with modern, scientific and good mining and engineering practices and accepted conservation principles and perform the operations in an efficient and economic manner with good and sufficient machinery and equipment;

(iv) determine the number of employees and their terms of employment and hire, direct and discharge all such employees who shall be employed by the Operator and subject to its control and direction;

(v) purchase or otherwise provide all necessary material and supplies;

(vi) purchase, lease or otherwise provide all necessary machinery and equipment (which may, subject to subparagraph 3(b)(iii), be acquired or leased from any Party hereto);

(vii) obtain services and supplies from contractors, consultants and suppliers;

(viii) comply, and require compliance of others doing work on the Property, with the requirements of Federal, provincial and local laws relating to employers' liability insurance, workers' compensation, social insurance, unemployment, fair employment and other similar applicable laws with respect to any work or operation conducted under this Afreement;

(ix) take all proper and reasonable steps for the protection of rights of surface owners against damage occasioned by operations to be conducted hereunder and pay such damages as may lawfully be determined as resulting from such operations;

(x) upon writton request, provide any Participant access to the Property in order to observe the conduct of Joint Venture operations or to undertake tests and assays, take aamples, and make copies of any data related to the Property, it being understood that such access shall be at the expense and peril of the Participant seeking access and shall not obstruct nor interfere with the operations conducted by the Operator;

(xi) review all invoices for approval, pay all approved invoices, maintain records in accordance with generally accepted accounting principles, and make available such records for the inspection of any Participant;

(xii) keep the Property free of liens and encumbrances of every character arising from operations (except liens for tares not yet due, other inchoate liens and liens contested in good faith by the Operator), and proceed with all diligence to contest or discharge any lien that is filed;

(xiii) pay, at the time and in the manner required by law, all Federal, provincial or local taxes (other than royalties and any taxes on income) assessed or levied against the Property or Joint Venture operations, provided that where tares in the opinion of the Management Committee, are wrongfully assessed or levied against the Property or Joint Venture operations, the Operator shall protest the assessment or levy within the time limit and in the manner prescribed by law and shall pursue the protest to final determination;

(xiv) within 30 days after the end of each quarter of an Operating Year provide summary statements for the quarter then ended setting out

(A) Program activities;

(B) actual costs as compared with the prior forecast of costs;

(C) estimated expenditures for the remainder of the Operating Year

together with a quarterly technical report of activities and such supporting invoices, receipts, records and reports as may be required by the Management Committee;

(xv) upon commencement of an Approved Development Program the Operator shall also provide within 60 days after the end of each Operating Year a balance sheet as at the last day of that Operating Year and a statement of source and application of 
funds for that Operating Year, with comparative statements for the previous Operating Year;

(xvi) obtain inclusive coverage insurance in a minimum amount of $\$ 3,000,000$ in the name of the Operator with all other Parties named as additional insureds. The insurance shall include public liability, bodily injury and property damage coverage, automobile public liability, bodily injury and property damage coverage, and employee liability insurance coverage (where necessary). Insurance shall also be obtained to cover the full insurable value of physical assets when they are acquired, with loss payable to the Operator (who shall have the obligation to distribute the proceeds in accordance with the Participating Interests of the Participants), or to any Chargee holding a mortgage, charge or other encumbrance made under Paragraph 2(e), according to its interest in the Property, provided that insurance proceeds of less than $\$ 50,000$ payable consequent on any one loss or occurrence need not be 80 distributed but may be applied by the Operator to the repair or replacement of damaged or lost ascots;

(rvii) regularly consult with the Participants concerning the operations and keep the Participants currently advised of all important matters arising in connection therewith; and

(xviii) comply with all terms and conditions of title documents relating to the Property and all things necessary to maintain the Property and the Option Agreement in good standing and in full force and effect for the benefit of the Joint Venture, provided that nothing herein shall oblige the Operator, as such, to make any payments in respect of the Salted Net Profits Distribution.

\section{(b) Indemnification of Operator}

Each Participant, proportionate to its Participating Interest, hereby agrees to indemnify and to hold harmless the Operator against any claim of or liability to any third person resulting from any act or omission of the Operator or its agents and employees in conducting operations pursuant to this Agreement, provided however that the Operator shall not be indemnified nor hold harmless by the Participants for any loss, damage, claim or liability resulting from the gross negligence or wilful misconduct of the Operator, its agents or employees, but no act or omission of the Operator, its agents or employees, shall of itself be deemed grose negligence or wilful misconduct if it is done or omitted at the instruction, or with the concurrence of the Management Committee. The Operator shall not be liable to the Participants for any loss or damage except for loss or damage resulting from the gross negligence or wilful misconduct of the Operator, its agents and employees.

\section{SECTION 6 - WORK PROGRAMS AND BUDGETS}

\section{(a) General}

All Joint Venture Operations shall be performed under Programs and budgets approved in accordance with this Afreement or otherwise by advance approval of the Management Committee.

\section{(b) Payment of Cost Share}

Each Participant shall pay its Cost Share in accordance with Paragraph 2(d).

\section{(c) Exploration Programs and Budgets}

(i) Draft plans and annual budget shall be submitted by the Operator in accordance with subparagraphs 5(a)(i) and (ii). The Participants shall have $\mathbf{3 0}$ days after receipt of such plans and budget within which to submit to the Operator their suggestions with respect thereto and the Operator shall in its discretion either amend such plans and budget in accordance with such suggestions or leave the same unaltered. A Management Committee meeting shall be called by the Operator, and failing that, any Participant in accordance with subparagraph $3(\mathrm{a})(\mathrm{ii})$, with a view to establishing 
an Approved Exploration Program which if established shall be confirmed by minutes of the Management Committoe.

(ii) So long as no Approved Exploration Program is in effect the Operator shall have the right and obligation to implement and carry out at its own discretion a minimum work program to keep the Property and the Option Agreement in good stending, and each of the Participants shall have an obligation and commitment to share the expenditures for such minimum program in accordance with its Participating Interest.

(iii) If, prior to the establishment of any Approved Development Program, there is, in respect of an Operating Year, no Approved Exploration Program in effect, or there is, in respect of that Operating Year, an Approved Exploration Program in effect involving budgeted expenditures of less than $60 \%$ of the budgeted expenditures involved in the immodiately preceding Approved Exploration Program then the following rules shall apply:

(A) any Participant may, by written notice to the Parties not later than January 31 in any year propose plans and a budget (including expenditures of at least $60 \%$ of the budgeted expenditures involved in the immediately preceding Approved Exploration Program) for Exploration Work;

(B) the Management Committee may establish an Approved Exploration Program besed on such proposed plans and budget which if 80 established shall be confirmed by minutes of the Management Committee;

(C) failing such establishment by the Management Committee within 45 days after such notice such Participant may, by a second notice to the Parties given no later than 60 days after such first notice, deem such plans and budget to be (and they shall thereupon, subject to clause (D), be deemed to be) an approved Exploration Program;

(D) if a second notice is given under clause (C) in respect of more than one proposal then the plans and budget comprising the proposal involving the greatest budgeted expenditures shall be the plans and budget deemed to be an Approved Exploration Program under that clause.

(d) Participating in the Program

(i) A Participant which elects in writing to accept an Approved Exploration Program shall thereby but not otherwise, become liable for its Cost Share of such Approved Exploration Program. Such election shall be made within 10 days of receipt of the Management Committee minutes confirming the establishment of such Approved Exploration Program, or within 10 days of the receipt of the second notice referred to in clause (c)(iii)(C), as the case may be. A Participant is relieved from participation in an Approved Exploration Program which it has not accepted.

(ii) Any Participant that does not elect to participate in an Approved Exploration Program prior to the date on which Joint Venture Expense totals not less than $\$ 1,000,000$, shall thereupon forfeit to the other Participants, pro rata to their respective Participating Interests, all interest of that Participant hereunder and under the Option Agreement, and shall erecute all such instruments as may reasonably be required to evidence such forfoiture. From and after the date of such forfeiture such Participant ahall cease, and be deemed to have ceased, to be a Party to this Agreement which may thereafter be amended or terminated without the consent of such Participant, provided that such forfeiture shall not relieve such Participant from any obligations theretofore accrued but unsatisfied.

(iii) After Joint Venture Expense totals not less than $\$ 1,000,000$, but not before, a Participant may elect (in the manner and within the time specified in subparagraph (i)) to participate in an Approved Exploration Program at a reduced percentage level (not being less than 3\%) less than its Participating Interest and shall thereby become liable for such share of the Joint Venture Expense relating to such Approved Exploration Program as will result in the percentage of total Joint Venture Expense paid by such Participant being equal to the reduced Participating Interest elected pursuant to this subparagraph (iii). 
(iv) Subject to subparagraph (v) the Participating Interest of any Participant who does not elect to participate in an Approved Exploration Program shall from time to time be reduced and the Participating Interests of the other Participants who have elected to participate shall be increased, such that the Participating Interest of each Participant shall be a percentage share being the percentage equivalent of the fraction the numerator of which is the aggregate amount contributed toward Joint Venture Expense by such Participant up to that time and the denominator of which is the aggregate amount so contributed by all Participants up to that time;

(v) When, under subparagraph (iv) a Participant's Participating Interest is reduced to less than a 3\% share, that Participating Interest shall be forfeited and shall be transferred to all Participants whose respective Participating Interests are each at least a 3\% share, in proportion to the respective Participating Interests of such last-mentioned Participants (or in such other ratio as they may agree upon) and the provisions of subparagraph (d) (ii) shall apply to such forfeiture mutatis mutandis, provided that if commercial production of ore from the Property has then com. menced forfeiture hereunder shall not relieve such Participant from contributing its proportionate share of ultimate costs of reclamation.

(vi) If a Participant does not elect to participato in an Approved Exploration Program, the Operator shall notify the other Participants of the deficiency in commitments and any of such other Participants may then elect to increase their contributions to that Approved Exploration Program in the ratio of their respective Participating Interests or in such other ratio as they may agree upon. If the deficiency is not 80 made up then that Approved Exploration Program shall be void, and the Management Committee may then establish another approved Exploration Program for the same Operating Year to which the provisions of this Paragraph (d) shall once again apply, provided that if the budget for the new Approved Exploration Program under this subparagraph (vi) is not less than $85 \%$ of the budget for such void Approved Exploration Program, each Participant that declined to participate in the void Approved Exploration Program shall be deemed to have declined to participate in the new Approved Exploration Program without submission thereof to such Participant.

\section{(a) Abandonment and Sale}

\section{SECTION 7 - ABANDONMENT OR SALE}

The Management Committee may decide to abandon a portion of the Property, provided that the decision for abandonment is made at least $\mathbf{1 8 0}$ days prior to the date on which any portion shall cease to be in good standing in the records of the appropriate governmental authority, and provided further that the Participants which voted against such abandonment may, within 30 days of notification of such proposed action and pro rata to their Participating Interests, at no cost and without further liability to the other Participants, acquire all interest of the abandoning Participants in such lands (subject only to the obligations related thereto under the Option Agreement) and the abandoning Participants shall forthwith quit-claim, assigm and convey, without warranty of title, but by good and proper instrument, all of their right, title and interest in such lands to the Participants electing to receive such assignment. Upon such assignment, the abandoning Participants shall be relieved from all obligations thereafter accruing, but not previously accrued, with respect to the interest assigned, the operations thereon, and the Production therefrom; provided however, the assigning Participant shall not be relieved of any obligations to which it was previously committed by electing to participate in a Program. Any lands acquired by a Participant under this Paragraph (a) shall thereafter not be in. cluded as part of the Property.

\section{(b) Sale Restricted to Participants}

Neither the Management Committee nor the Operator has the right to sell any interest in or title to all or any part of the Property and any sale of a Participating Interest in the Property hereunder may only be made by a Participant. 


\section{(c) No Right of First Refusal}

Subject to Section 9, no Participant shall have any right to acquire the interest herein and in the Property of any other Participant that intends to sell or otherwise dispose of that interest or any portion thereof except

(i) any Participant that makes any such sale or other disposition shall give prompt notice thereof to all other Participants, and shall complete such sale or disposition in compliance with the requirements of subparagraph (ii); and

(ii) any and all sales, assignments, transfers or other dispositions made by any Participant (or its successors in interest) of its Participating Intorest ghall be subject to the terms, covenants and conditions of this Agreement and all applicable laws and regulations. The provisions of this Agreement shall be deemed to be covenants running with the Participating Interest acquired hereunder and all such sales, assignments, transfer and dispositions thereof. Tho Participants shall require any and all transferees of a Participating Interest to execute a counterpart of this Agreement and the Option Agreement in the same manner and to the same extent as though the transferee had been a party in the first instance to this Agreement, and an "Optionee" as defined in the Option Afgreement.

\section{SECTION 8 - NO UNIIATERAL TERMINATION OF INTEREST}

No Participant may unilaterally abandon, quit-claim or terminate its Participating Interest in the Property, and each Participant shall, save as otherwise in this Agreement provided, remain liable, in the ratio of its Participating Interest, for all obligations of the Joint Venture as owner, occupier or user of the Property.

\section{SECTION 9 - DEVELOPMENT WORK}

\section{(a) Initiation of Development Work}

(i) If the results of Exploration Work conducted on the Property are such that, in the judgment of the Operator or any Participant, Development Work ought to be considered, then the Operator or any such Participant may present to the Management Committee a proposal to commission a feasibility study. A meeting of the Manegement Committee shall bo held to consider the proposal and shall be convened within 90 days after receipt of such proposal.

(ii) The purpose of the fessibility study shall be to determine whether or not minerals in commercial quantities are located on the Property and whether it is commercially feasible to bring a mine into production on the Property and, if so, to recommend by what techniques, at what rates, within what time period and at what anticipated costs (including any anticipated costs associated with acquiring additional mineral claims) Production should be carried on. Any feasibility study commissioned under this Agreement shall be in such form, and shall contain such informetion, as will meet the requirements in those respects of lenders of senior financing for mining operations in Canada.

(b) Commissioning of Feasibility Study

(i) The decision to commission a feasibility study at Joint Venture Expense shall be made, and the plans and budget for that feasibility study shall be established, by the Management Committee. The plans and budget 80 established shall then be deemed to be an Approved Bxploration Program and shall be confirmed by minutes of the Management Committee. Paragraph 6(d) shall apply, mutatis mutandis, to participation in any such Program.

(ii) If the Management Committee has considered a proposal to commission a feasibility study but has not commissioned the feasibility study then any Participant may commission the feasibility study at its own expense. If an Approved Development Program is ultimately established based on such feasibility study then the Joint Venture shall reimburse such Participant for the expense 80 incurred. 


\section{(c) Consideration of Feasibility Study}

The findings and recommendations contained in a feasibility study shall be considered by the Management Committee at a meeting to be held on not less than 45 nor more than 90 days' notice after receipt of the feasibility study by the Participants. The Management Committee shall decide whether the feasibility study needs revision or clarification, and in the event that it does, the fessibility study shall be returned for such purposes. The meeting shall be re-convened on no fewer than 20 days' notice after receipt by the Participants of such revisions or clarifications, if any. If the feasibility study does not require revision or clarification, or after the same is made, the Management Committoe shall (but only if the feasibility study contains a positive recommendation to place the Property into commercial production, and demonstrates the fessibility thereof) in accordance with Paragraph (d) consider the establishment of an Approved Development Program. For such purpose the Management Committee shall instruct the Operator to propose (within such time as the Management Committee may specify) a Program of Development Wort based upon the findings and recommendations of the feasibility study. Such proposed Program shall be submitted to the Participants and shall contain such information in such detail (in addition to the information contained in the feasibility study) and by such date as the Management Committee may specifiy.

\section{(d) Establishment of an Approved Development Program}

Within 60 days after the submisaion of the proposed Program of Development Work to the Participants, the Management Committee shall meet to consider the proposed Program of Development Work with a view to establishing an Approved Development Program. The following rules shall apply:

(i) If $75 \%$ or more of the Participating Interests as represented on the Management Committee support Development Work based on such proposed Program then such Program shall be deemed to have been approved and shall become an Approved Development Program;

(ii) If $50 \%$ or more, but less than $75 \%$ of the Participating Interests so represented support such Development Work then there shall be a delay of 6 months after which the matter shall be again considered by the Management Committee and if, upon such re-consideration, 50\% or more of the Participating Interests then so represented support such Development Work then such Program shall be deemed to have been approved and shall become an Approved Development Program;

(iii) If less than 50\% of the Participating Interests support such Development Work then any Participant may, by notice to the other Participants, propose a reexamination period of 2 years following such notice and if such period is so propoeed then, at the expiry of such period, the Management Committee shall, at the election (to be exercised on no less than 60 days' notice to all other Participants) of the Participant who proposed such period, meet and again consider the proposed program of Development Work which, if then supported by $50 \%$ or more of the Participating Interests represented on the Management Committee, shall then be deemed to have been approved and shall become an Approved Development Program;

(iv) If the proposed Program of Development Work is not approved at a meeting, if any, held pursuant to subparagraph (iii) at the expiry of such re-examination period then, but not before then, the Participant that convened such meeting may, within 90 days thereaftor, give a notice under Paragraph (g).

\section{(e) Participation in an Approved Development Program}

(i) Forthwith after the establishment under Paragraph (d) of an Approved Development Program, the Management Committee shall give each Participant written notice thereof. Within 20 days after such notice is given each Participant shall indicate in writing whether it elects to participate in the Approved Develpment Program and, if so, whether at a reduced Particjpating Interest. 
(ii) Ercept as otherwise provided in Paragraph (f), the provisions of Paragraph 6(d) shall apply, mutatis mutandis, to decisions of Participants respocting participation in an Approved Development Program.

(I) Compensation for Forfeited or Reduced Interest

A Participant whose Participating Interest has been forfeitod under subparagraph 6(d)(iv) after an Approved Development Program has been approved shall be entitled to receive, at Joint Venture Expense, compensation for all the moneys that Participant has theretofore expended under this Agreement plus interest thereon from the date of forfeiture (not, however, in the aggregate exceeding $200 \%$ thereof) at a rate per annum two percentage points in ercess of the prime commercial lending rate in Canada from time to time of Bank of Nova Scotia. Such compensation shall be paid by the Joint Venture in five annual payments, beginning on the last day of the month following the month in which Production in commercial quantities is first shipped from the Property, and on each of the four anniversary dates thereof, each such payment to include an equal por. tion of such expenditures plus acerued interest thereon to the date of payment. Such compensation may be prepaid without notice or penalty.

\section{(g) Forced Buy-Sell; Disagreement on Production Decision}

(i) A notice under this Section may only be given as permitted in Paragraph (d). A notice given by a Participant (in this Section called the "Offeror") under this Paragraph shall be given to all other Participants (in this Section called the "Offerees") and shall contain

(A) the Offeror's opinion of the fair value of the aggregate Participating Interests held by all Participants;

(B) a summary of the basis upon which such opinion has been reached;

(C) the price of each Offeree's Participating Interest, being its percentage interest multiplied by the fair value referred to in clause (A);

(D) the price of each Offeror's Participating Interest, being its percentage interest multiplied by the fair value referred to in clause (A);

(E) an unconditional offer to purchase from each of the Offerees all, but not lese than all of their respective Participating Interests at the said prices therefor as above determined;

(F) an offer to sell to each of the Offerees all, but not less than all, the Offeror's

Participating Interest at the said price therefor as above determined; and

(G) the terms of payment of such purchase or sale, which shall be by cash or certified cheque payable in full on the date of closing.

(ii) In order to be effective, such offer shall also be accompanied by a certified cheque of the Offeror payable to each of the Offerees in the amount of $5 \%$ of the price offered for their respective Participating Interests which shall be hold by the Offerees as a deposit pending the completion of the transaction and to be credited toward such purchsse price on closing, or which shall be returned without delay by each Offeree that elects to purchase the interest of the Offeror as provided in subparagraph (iv).

(iii) The Offerees shall, within 60 days of the receipt of the notice under subparagraph (i) accept either of the offers contained in such notice. In the event any Offeree does not accept either of the offers contained in such notice within such period of 60 days, such Offeree shall be deemed to have accepted the offer of the Offeror to purchase all, but not less than all, such Offeree's Participating Interest.

(iv) If any of the Offerees accept the offer of the Offeror to sell the Participating Interest of the Offeror, then such Offerees shall purchase and the Offeror shall sell such Participating Intereat to such Offerees for the purchase price determined pursuant to clause (i)(D) and, if more than one Offeree so accepts such offer, on a pro rata basis, proportionate to the respective Participating Interests of such Offerees. 
Upon any sale of the Offeror's Participating Interest under this subparagraph the Offeror's offer to purchese the Participating Interests of the Offerees shall be deemed to have been withdrawn before acceptance, and notwithstanding subparagraph (iii) neither the Offeror nor any Offeree described in this subparagraph (iv) shall then be bound or permitted by this Paragraph (g) to purchase the Participating Interest of any Offeree.

(v) If all of the Offerees accept or are deemed to accept the offer of the Offeror to purchsse all thoir respective Participating Interests then the Offerees shall sell and the Offeror ahall purchase all the respective Participating Interests of the Offerees for the purchase price determined pursuant to clause (i)(C).

(vi) Any transaction of purchase and sale pursuant to this Paragraph (g) shall be completed within 90 days after the 60-day period referred to in subparagraph (iii) and the purchsser in such transaction shall pay the purchese price on the date of cloeing, provided that if any third-party approval is required in connection with the proposed purchase and application for such approval has been made during such 90-day period, and such applications continue thereafter to be prosecuted with reasonable diligence, the date of cloeing shall be extended for such longer period thereaftor as may reasonably be necessary for the prosecution to conclusion of such application.

\section{SECTION 10 - PRODUCTION}

\section{(a) Production Rate}

The actual rate of production of Product shall, as nearly as may be practicable, be the design rate as described in the Approved Development Program or the feasibility study upon which such Program is based, but the Management Committee may increase such actual rate to a rate not exceeding $116 \%$ of such design rate. The actual rate shall not (ercept by reason of unavoidable production problems) be reduced below such design rate, nor increased to more than $115 \%$ thereof; without the unanimous consent of the Participants.

\section{(b) Taking in Kind}

(i) Each Participant shall take in kind and separately dispose of its share of the Product and shall individually bear any extra expenditures necessitated thereby. Notwithstanding the provisions of Paragraph (d), if a Participant is in default of payment of its Cost Share in sccordance with Paragraph 11(d), such Participant's share of the Product will become Joint Venture Property if the default is not cured within the time limit set out in Paragraph 11(d).

(ii) All Product shall be divided among the Participants according to their respective Participating Intorests, and each Participant shall receive Product of like quality to that recoived by each other Participant and, to the extent such division is impractical, a mothod of making rolevant adjustments shall be determined by the Participants.

(iii) Each Participant shall receive its share of Product weighed, sampled, assayed and delivered at a point of delivery in accordance with delivery procedures to be agreed upon by the Participants prior to the commencement of commercial production. Doterminations under this Paragraph (b) will be final and no adjustments shall be made as a result of final determinations and assays made at a smelter or elsewhere.

(iv) The Operator shall maintain records of the quantity and quality of Product taken by eech Participent and shall furnish the Participants with written monthly reports in respect thereof.

(c) Failure to Take in Kind

If a Participant has not made the necessary arrangements to take in kind, or place in storage in accordance with Paragraph (d) its share of Product, the Operator may give no- 
tice to that Participant that $\mathbf{3 0}$ days after such notice such share will be sold or stored for the account of that Participant, and if sold all costs of storage and sale (including com. missions and the Operator's selling expenses) will be deducted by the Operator from the proceeds of sale to be paid to the Participant. If such share is stored and not sold the Participant shall promptly reimburse the Operator for the cost of such storage as it is incurred and is billed by the Operator to the Participant. In effecting any sale under this Paragraph the Operator may commit for sale that Participant's share of future Product for a period not exceeding one year.

\section{(d) Storage of Product}

The Operator shall, if requested by a Participant, store in a suitable location the Product owned by such Participant. Such Product shall be stored in a location where it will not interfere with Production, and each Participant shall only be entitled to use for storage purposes its respective share of any area so used for storage, and all of the costs involved in arranging and providing such storage shall be billed directly to and be the sole responsibility of the Participant whose Product is so stored. Once stored, such Product ahall no longer form any part of the Joint Venture Property and the Operator shall be under no further reaponsibility with respect thereto save to provide assiatance in dispatching the shipment thereof from its place of storage when requested to do so by the Participant owning such Product. The Operator's charges for such assistance and any other related matters shall be billed directly to and be the sole responsibility of such Participant.

\section{(o) Salted Net Profits Distribution}

Each Participant agrees that it will pay to the "Optionor" under the Option Agreement, at the times and in the manner provided in the Option Agreement, that portion of the Salted Net Profits Distribution to which the Optionor is entitled in respect of the Production delivered to such Participant, to be calculated for the purpose as if

(i) such Production was the entire Production from the Property,

(ii) such Participant was the only "Optionee" under the Option Agreement, and

(iii) no "Operating Expenses" or "Preproduction Expenditures" wore made thereunder except those made by the Participant and its predecessors in title.

For greater certainty, the Parties agree that it is their intention that the obligation to make the Salted Net Profits Distribution shall be borne by the Participants in proportion to their respective Participating Interests, except as the extent of such participation shail be varied due to differences in costs of sale and net smelter returns attributable to the Production of the respective Participants. If in the opinion of any Participant the allocation rule hereinabove set forth does not effect an equitable sharing of the Salted Net Profits Distribution costs among the Participants the determination of an equitable allocation rule shall, in the absence of unanimous agreement, be referred to arbitration under Section 13. Each Participant shall make available to the Operator and to the Optionor under the Option Agreement all financial data reasonably required by them to verify compliance with the provisions of the Option Agreement.

\section{SECTION 11 - LIABILITY OF PARTICIPANTS}

\section{(a) Separate and Not Joint}

The rights, duties, obligations and liabilities of the Participants shall be separate as to each Participant's respective Participating Interest and not joint nor joint and several. Each Participant shall be responsible only for its obligations herein set forth. It is not the intention of the Participants to create a mining, commercial or other partnership or agency relationship between the Participants and this Agreement shall not be constructod so as to render the Participants liable as partners or as creating a mining, com. mercial or other partnership. 


\section{(b) Ownership of Property}

The Participants shall hold and own their respective beneficial interests in the Property as tonants in common. Each Participant shall be responsible only for its obligations as herein sot forth and shall not in any way be obligated for the debts or other obligations of any other Participent except as indemnitor of the Operator to the extent required by Paragraph 5(b).

\section{(c) No Partition}

No Party shall, during the term of this Agreement, erercise any right to apply for partition of the Property or any other Joint Venture Assets or any portion thereof or for sale thereof in lieu of partition.

\section{(d) Defoult}

(i) All amounts payable by a Participant hereunder shall be paid within 30 . days after that Participant has been invoiced therefor. If not 80 paid the Operator or the Management Committee may give that Participant written notice that payment has not been made. If payment is not made within a further 30 days after such written notice is given then that Participant shall be deemed to be in default under this Agreement.

(ii) If any Participant fails to observe or perform any condition or covenant herein on its part to be obeerved or performed (other than an obligation to pay money) the Operator or the Management Committee may give that Participant written notice specifying such failure. If that Participant does not, within 60 days aftor such written notice is given, commence and thereafter continue to diligently remedy such failure (to the extent that the same may then be remedied) then that Participant shall be deemed to bo in default under this Agreement.

(iii) A Participant which disputes its liability to pay any amount referred to in subparagraph (i) or to remedy any failure reforred to in subparagraph (ii) shall nevertheless pay such amount or remedy such failure, as the case may be, but without prejudice to its right to dispute its liability therefor. Any such dispute shall be submitted to arbitration as hereinafter provided.

(iv) If, prior to the eatablishment of an Approved Development Program, a Participant is deemed to be in default under this Agreement then the Participating Interest of such Participant shall, without compensation therefor, be forfeited to the othor Participanta, pro rata to thoir respective Participating Interests, but the Participant whose Participating Interest is so forfeited shall nevertheless remain liable for the fulfillment of all its obligations hereunder up to the time of such forfeiture.

(v) If, after the establishment of an Approved Development Program, a Participant is deemed to be in default under this Agreement then the Operator, or the Management Committee, on behalf of the Operator and the other Participants

(A) ahall have a lien on the share of Product belonging to such Participant to recoup the losses and expenses occasioned by such default, which lien may be onforced by sale of such share of Product;

(B) may, to recoup the losses and expenses occasioned by such default, sell (either to one or more of the other Participants, or to third parties, or part one way and part the other but subject to Paragraph 7(c)) all or part of the Participating Interest of that Participant; and

(C) may, to recoup such losses and expenses, take legal proceedings against such Participant.

\section{SECTION 12 - TERM AND MODIFICATION}

\section{(a) Term of this Agreement}

Subject to Paragraph (b) this Agreement shall be in full force and effect for so long as more than ono Participant holds a Participating Interest in the Property. 


\section{(b) Rule Against Perpetuities}

If any right, power or interest of any Venturer in the Property or any part thereof would violate the rule against perpetuities then such right, power or interest shall terminate at the expiration of 20 years after the death of the last survivor of all the lineal descendents of His late Majesty King George VI of England, living on the date of execution of this Agreement.

\section{(c) Effect of Termination}

The termination of this Agreement and the distribution of Joint Venture Assets shall not relieve the Participants from any obligations accruing to them under this Agreement or in consequence of operations performed pursuant to this Agreement prior to the expiration or termination date.

\section{(d) Method of Modification}

No change, modification or alteration of this Agreement shall be valid unless the same is made in writing, signed by all of the Parties; and no course of dealing between the Parties shall be construed 80 as to alter the terms of this Agreement. Amendments in writing may be made at any time and from time to time by concurrence of all of the Parties. For the purposes of this Paragraph (d) and Paragraph 17(d) any Participant whose Participating Intorest has been forfeited to the other Participants shall be deemed not to be and never to have been a Party.

\section{SECTION 13 - ARBITRATION}

\section{(a) Settlement of Disputes}

If any differences or dispute shall arise between any of the Parties in respect to any matter where it is provided in any other part of this Agreement that such dispute or such matter shall be arbitrated or submitted to arbitration, or in respect of any other matter arising under the Afreement, such dispute shall be submitted to arbitration under and pursuant to the Arbitration Act of British Columbia. Such dispute shall be referred by the Parties affected thereby to an Arbitrator who shall be agreed upon by such Parties and, failing such agreement within 4 weeks after notice by any such Party then an arbitrator may be named as provided in the Arbitration Act. The arbitrator so appointed shall sit in Vancouver, Britioh Columbia, unless there is unanimous agreement of such Parties that he shall sit at another place, and shall hear and dispose of such dispute in such manner as the arbitrator, in his discretion, shall determine, but in so doing shall be required to receive the submissions of such Parties. The decision of the arbitrator shall be rendered in writing with all reasonable speed and shall be final and binding upon such Parties.

\section{(b) Costs of Arbitration}

If the Parties to the arbitration cannot asree as to the respective shares of the costs of arbitration to be borne by them, the arbitrator shall determine what part of the costs and expenses incurred in any such proceeding shall be borne by each of them.

\section{SECTION 14 - NOTICES}

(a) Except as otherwise specified herein any notice given hereunder shall be given in writing, by delivery in person to a named representative or alternate or by mail, telex or tolegraph properly addressed to the Party to whom given, with postage and charges prepaid. A notice given under any provision hereof shall be deemed given only when received by a Party to whom such notice is directed; ercept that any notice given by telex or telegraph properly addressed to the Party to whom directed shall be deemed given to and received by that Party on the business day next following the date on which such notice is telezed or filed with an operating telegraph com. pany for immediate transmission by telegraph. 
(b) Each Party's proper address shall be as set forth on page 1 hereof until such Party specifies another address by written notice to all other Parties.

\section{SECTION.15 - CONIDINTIALITY}

(a) The Parties agree that all information they may receive as a result of or in connection with the work carried out under the provisions of this Agreement shall be the exclusive property of the Participants, shall be classified as secret and treated as proprietary and shall not be shared or traded with others without the prior consent of the Participants. Notwithstanding the foregoing any Party may at any time and without the consent of the others share all or any part of such information with

(i) a company that is a parent, subsidiary or subsidiary of a parent of that Party or is otherwise affiliated through common control of that Party;

(ii) with governments or agencies thereof or other regulatory authorities having jurisdiction (including stock exchanges), in accordance with the requirements thereof;

(iii) with shareholders and the public in accordance with any timely disclosure or other reporting laws or policies from time to time in force.

(b) Each Party agrees that it shall observe the restrictions contained in Paragraph (a) not only while it shall be a Party hereto, but also for a period of two years thereafter.

(c) All news releases or public announcements respecting any aspect of the Joint Venture or respecting the Property made by any Party shall, where practicable, be first approved as to contents by the other Parties.

\section{SECTION 16 - FORCE MAJEURE}

(a) The obligations hereunder of the Operator and any Participant, except the obligations to pay the Cost Share of a Program and to keep the Property in good standing under the lawe or instruments applicable thereto, shall be suspended during such time and to the extent that the performance of its obligations is prevented, in whole or in part, by strikes, walk-outs, acts of God, actions of elements, laws, rules and regulations of governmental bodies or agencies thereof, unavoidable accidents, delays in transportation, inability to obtain or delay in obtaining necessary materials, facilities and equipment in the open market, or any other cause, orcept financial, whethar similar or dissimilar to those specifically mentioned, beyond the reasonable control of the Operator or such Participant, as the case may be.

(b) If any such cause shall arise the Party affected shall, as soon as practical, advise the other Parties in writing of the occurrence of such cause, and shall take such action as may reasonably be available to it to endeavour to eliminate such cause, provided that no Party shall be required to settle strikes, walk-outs, or other labour difficulties contrary to its wishes.

\section{SECTION 17 - MISCELLANEOUS}

\section{(a) Construction of Agreement}

This Agreement shall be interpreted and construed in accordance with the laws in force from time to time in British Columbia. If any provision of this Agreement is in conflict or inconsistent with the applicable law then that provision shall be severed from this Agreement and an equitable adjustment shall be made and necessary further provisions ahall be agreed upon so as to give effoct to the intention of the Parties as expressed in this Agreement at the time of its execution.

\section{(b) Further Acts}

The Parties shall from time to time and at all times do such further acts and things and execute all such further documents and instruments as may be reasonably required in order to carry out and implement the true intent and meaning of this Agreement. 
(c) Successors and Assigns

This Agreement shall enure to the benefit of and be binding upon the Parties hereto and their respective successors and, subject to Paragraph 7(c), assigms.

\section{(d) Entire Agreement}

All of the agreements and understandings between the Parties with respect to the Joint Venture and with respect to the Property are embodied in this Agreement and the Option Agreement, and this Agreement supersedes all prior agreements (except the Option Agreement) and understandings between the Parties with respect to the Joint Venture and with respect to the Property. Any modification, alteration or amendment of this Agreement shall in writing dated subsequently to the date hereof and duly executed by each of the Parties.

\section{SECTION 18 - AREA OF INTEREST}

\section{(a) Area of Interest}

There is hereby established an "Area of Interest" being any part of the lands lying within three kilometers of the external perimeter of the mineral claims listed in Schedule "A". Any interest in any lands in the Area of Interest acquired by or on behalf of any of the Parties shall, subject to the Option Agreement, be deemed to have been acquired on behalf of all the Parties.

\section{(b) Management Committee Review}

Any Party acquiring any interest in any lands any part of which is included in the Area of Interest shall promptly advise the Management Committeo thereof, specifying the terms of such acquisition and shall also furnish all data in its possession related to mineralization on, and the geology of such lands. The Management Committee shall, as soon as convenient thereafter, review such acquisition and shall

(i) determine that such interest shall be retained by the Joint Venture in which case it shall for all purposes hereof become part of the Property and the Participants (including the Party acquiring such interest if a Participant) shall, according to their respective Participating Interests, reimburse the Party acquiring such interest its acquisition costs and expenses and agree to indemnify such Party in respect of any obligations incurred or assumed by it as part of such acquisition; or

(ii) determine that such interest shall not be retained by the Joint Venture in which case such interest ahall, notwithstanding Paragraph (a), be retained by the Party acquiring such interest free from any claim of any other Party under this Agreement, but subject nevertheless to the provisions of the Option Agreement.

\section{(c) Transfers}

The Parties shall execute and deliver all transfer and other documents necessary to ovidence and give effect to the disposition of such interest pursuant to Paragraph (b).

IN WITNESS WHIRREOF this Agreement has been executed by the Parties the day and yoar first above written.

\section{THE CORPORATE SEAL OF GOLDEN TOUCH MINING LIMITED was hereunto affired in the presence of:}

THE CORPORATE SEAL Of PRUDENT EXPLORATIONS LTD. was hereunto affired in the presence of: 